\title{
BAHÂ SAÎD BEY'İN HAYATI, ESERLERİ VE ANADOLU'DAKİ ALEVÎ-BEKTAŞÎ-NUSAYRÎ ZÜMRELERİ İLE İLGİLİ ÇALIŞMALARI
}

Bahâ Saîd Bey's Life, Works and His Studies on Anatolian Communities of Alevies, Bektashies and Nusayries

\section{Öz}

Bahâ Saîd Bey (1882-1939) seçkin kişiliğiyle varlığını vatan ve milletine adayan millî kahramanlarımızdan biridir. $\mathrm{O}$, dönemin yönetimi tarafından Anadolu'daki Alevî-Bektaşî zümrelerini, Tahtac1, Çepni ve Hardal Türkmenlerini, soy, dil, mezhep ve geleneklerini yakından tetkîk etmek için görevlendirilmiştir. Entellektüel bir kişiliğe sahip olan Bahâ Saîd'in, uzun bir çalışmasının sonucu AlevîlikBektaşîlikle ilgili araştırmaları, başta Türk Yurdu mecmuası olmak üzere Muhibbân, Memleket ve Meslek gibi gazete ve dergilerde neşredilmiștir. Türk Yurdu'nda yayınlanan makaleleri, Türkiye'de Alevî zümreleri arasında bilimsel yöntemlerle yapılmış ve detayl bilgiler veren saha arasstırmalarından oluşmaktadır. Bahâ Saîd'in alan araștırmaları uzun bir dönemi kapsamaktadır. Dolayısıyla araştırma sonunda aktardığı bilgiler oldukça önem arz etmektedir. Onun Alevîlik-Bektaşîlik ve Nusayrîlik üzerine yaptığı bu araștırmalar Türkiye'de ilklerden olması nedeniyle ayrı bir değere sahiptir. Bu çalışmada, Bahâ Saîd'in Alevî-Bektaşî ve Nusayrî zümrelerine yönelik yaptığı araștırmaları ve onun söz konusu zümreler hakkındaki düșüncelerinin tespiti amaçlanmıştır. Bahâ Saîd, saha

\section{Abstract}

Bahâ Saîd Bey (1882-1939) is one of our national heroes during the transition period from the Ottoman to the Republic and dedicated his existence to his country and nation with his distinguished personality. $\mathrm{He}$ was appointed by the administration of the period to closely examine the Alevi-Bektashi communities, Tahtaci, Chetmi and Hardal Turkmens in Anatolia in terms of their ancesters, languages, sects and traditions. Having an intellectual personality, Bahâ Saîd's researches on Alevism Bektashism were published in newspapers and magazines such as Muhibbân, Memleket and Meslek, especially in the Türk Yurdu journal. His articles published in the Türk Yurdu journal are consist of field researches made by scientific methods and they supply detailed information. Bahâ Saîd's field researches cover a long period. Therefore, the information given at the end of the researches is very important. His researches on the Alevi-Bektashi and Nusayriya have a special importance as they are the firsts in Turkey. In this study, it was aimed to determine Bahâ Saîd's researches on Alevi-

1 Dr. Öğr. Üyesi, Osmaniye Korkut Ata Üniversitesi İlahiyat Fakültesi, Kelâm ve İtikadî İslâm Mezhepleri Anabilim Dalı, Osmaniye, Türkiye / e-posta: suleymancam@osmaniye.edu.tr /ORCID: 0000-0002-4588-8491.

\begin{tabular}{ccc}
\hline $\begin{array}{c}\text { Başvuru|Submission } \\
\text { 31.10.2020 }\end{array}$ & $\begin{array}{c}\text { Kabul|Accept } \\
25.12 .2020\end{array}$ & $\begin{array}{c}\text { Yayın | Publish } \\
30.12 .2020\end{array}$ \\
\hline DOI: & $10.18403 /$ emakalat.819155 &
\end{tabular}


araștırmalarında Alevî-Bektașî inancının kökenleri ve âyinleri hakkında genel olarak bilgi vermiştir. Ayrica bu çalışmada, katılımcı gözlem ve mülakat tekniklerini uygulayan Bahâ Saîd'in, Anadolu'daki başta Alevî ve Bektaşîler olmak üzere diğer zümrelerin inanç ve kültür sistemlerini incelediği ve onlarda eski Türk kültür izlerinin varlığını tespit ettiği görülmüştür.

Anahtar Kelimeler: Mezhepler Tarihi, Bahâ Saîd, Alevî, Bektaşî, Nusayrî
Bektashi and Nusayriya communities and his thoughts on these communities. Bahâ Saîd gave general information about the origins and rites of the AleviBektashi belief in his field researches. In addition, in this study, it was observed that Bahâ Saîd, who applied participatory observation and interview techniques, examined the belief and cultural systems of other communities in Anatolia, especially Alevis and Bektashis, and determined the presence of traces of ancient Turkish culture in them.

Key Words: History of Sects, Bahâ Saîd, Alevi, Bektashi, Nusayriya.

\section{GİRIŞ}

XIX. Yüzyıldan itibaren Anadolu'daki Alevî-Bektaşî zümreler hakkında yapılan ilk çalışmaların batılı araştırmacılar tarafından gerçekleştirildiğini görmekteyiz. Bu dönemde Batıda AlevîlikBektaşîlik hakkında çalışma yapan bilim adamları arasında Browne, V. Luschan, Jacop ve Hasluck gibi araştırmacılar ön plana çıkmıştır. ${ }^{2}$ Söz konusu araştırmalar; Alevî-Bektaşî zümrelerin Anadolu'daki "Hıristiyan unsurların ardılları" olduğu veya Alevîliğin İslâm'ı içinden baltalamak için İran'ın yapmış olduğu bir nevi intikam hareketi", olarak değerlendirilmiştir. ${ }^{3}$ Yine bu dönemde bazı batılı araştırmacılar, Anadolu Alevîlerine bir "Hıristiyan kırması", Bektaşîlere ise "Hıristiyanlık etkisini taşıdığı"nı gündeme getirmeye çalışmışlardır. ${ }^{4}$ Batılı araştırmacıların bu tezlerine karşı devlet yetkilileri, savunma duygusuyla herekete geçmiş ve Alevî-Bektaşî topluluklar hakkında araştırmalar yapılmaya başlanmıştır. ${ }^{5}$

Bahâ Saîd, bu konuda ilk araştırma yapanlardan biri olarak dikkat çekmektedir. Çünkü o, Avrupalı ilim adamlarının Anadolu'daki Alevî-Bektaşi inanc1 ve diğer inanç mensupları hakkındaki görüşlerin tamamının yanlış olduğuna cevap vermek için Alevî ve Bektaşîler'in yaşadıkları bölgelerde bizzat katılımcı gözlem ile

2 Baki Öz, İttihat-Terakki ve Bektaşîler, (İstanbul: Can Yayınları, 2004), 152.

3 Serdar Sarısır, "Alevî-Bektaşî Zümreler Hakkında Yapılan İlk Araştırmalar", IV. Uluslararası Alevîlik ve Bekraşîlik Sempozyumu Bildiriler Kitabı, (Ankara: 18-20 Ekim 2018), 420.

4 Öz, İttihat-Terakki ve Bektaşîler, 153.

5 Sarısır, "Alevî-Bektaşî Zümreler Hakkında Yapılan İlk Araştırmalar", 421. 
alan araştırması denilen metotlarla uzun yıllar araştırmalar yapmıştır. ${ }^{6}$ Ancak Alevî-Bektaşîler hakkında daha sonra yapılan araştırmalara bakıldığında Bahâ Saîd'e hiç yer verilmediği görülmüștür. Oysa onun ömrü, "Anadolu'nun iç yüzünü” ele alan çalışmalar yapmakla geçmiştir. Bahâ Saîd'in söz konusu zümrelerle ilgili araştırmaları, son dönemde yapılan çalışmalara rehberlik eder mahiyettedir. ${ }^{7}$

Görkem, Bahâ Saîd Bey'in önce, özel merak ve ilgisi sebebiyle daha sonra İttihat ve Terakki'nin görevlendirmesiyle Anadolu'daki Alevî-Bektaşî zümreler hakkında araştırmalar yaptığını beyan eder. ${ }^{8}$ Görkem, onun zümrelerle ilgili çalışmalarının katılımlı gözlem ve mülakat tekniklerine dayandığ için bilimsel olduğunu açıklamıștır. ${ }^{9}$ Tevetoğlu ise Itttihat ve Terakki'nin kurucularından Sadrazam Talat Paşa'nın, Gökalp’in tavsiyesiyle, 1914-1915 yıllarında Bahâ Saîd’i, "Anadolu'da tarikatların, Alevî zümrelerinin, Tahtacı, Çepni, Hardal Türkmenlerinin incelenmesi ile de vazifelendirdiğini" söyemiştir. ${ }^{10}$ Bütün bu araştırmalardan onun Anadolu'daki Alevî-Bektaşî zümrelerinin inancı ve Anadolu'daki mezhepler hakkında geniş ve önemli bilgilere sahip olduğu anlaşılmaktadır. Dolayısıyla söz konusu zümreler hakkında ilk çalışmaları yapanlar arasında, gerek kendi merak ve ilgisi gerekse de devlet yetkilileri tarafindan görevlendirilmesi yönüyle Bahâ Saîd ismi ön plana çıkmaktadır.

Anadolu'daki Alevî-Bektaşî zümreler hakkında yapılan çalışmaların biri resmi diğeri ise dönemin iktidarı ile güçlü bağları olan Türk Ocağı ve onun yayın organı Türk Yurdu dergisi olmak üzere iki ayağı bulunmaktadır. ${ }^{11}$ Bahâ Saîd’in yaptığı söz konusu

6 Orhan Türkdoğan, Alevî-Bektaşî Kimliği/Sosyo Antropolojik Araştırma, (İstanbul: Timaş Yayınları 1995), 43-46.

7 Öz, İttihat-Terakki ve Bektaşîler, 234.

8 Bahâ Saîd Bey, Türkiye'de Alevî-Bektaşî, Ahî ve Nusayrî Zümreleri, (Girişi yazan ve yayına hazırlayan: İsmail Görkem), (Ankara: Kültür Bakanlığı Yayınları 2000), 29; Öz, İttihat-Terakki ve Bektaşîler, 226-231; Ayrıca Bahâ Saîd'in Anadolu'da ilk Alevî-Bektaşî araştırmaları hakkında bkz. Ersin Kılıç, AlevîBektaşîlerin Millî Mücadeledeki Rolü ve Atatürk ile İişkileri, (İstanbul: Marmara Üniversitesi, Türkiyat Araştırmaları Enstitüsü, Yüksek Lisans Tezi, 2011), 3338.

9 Bahâ Saîd, Türkiye'de Alevî̀-Bektaşî, Ahî ve Nusayrî Zümreleri, 27.

10 Fethi Tevetoğlu, "Millî Mücadele Kahramanlarından: Bahâ Saîd Bey", (Biga: 1882-İstanbul 16 Ekim 1939), Atatürk Araştırma Merkezi Dergisi, 6/16, (Kasım 1989), 209; Ayrıca bkz. Hilmi Ziya Ülken, Türkiye’de Çağdaş Düşünce Tarihi, (İstanbul: Ülken Yayınlar1, 3. Bask1, 1992), 257'de 302. Dipnot; Enver Behnan Şapolyo, Mezhepler ve Tarikatlar Tarihi, (İstanbul: Türkiye Yayınları, 1964), 331.

11 Sarısır, "Alevî-Bektaşî Zümreler Hakkında Yapılan İlk Araştırmalar”, 419. 
araştırmaların çoğu ilk olarak Türk Yurdu dergisinde yayınlanmış olup bu durum derginin yapılan çalışmalara dair misyonu hakkında fikir vermektedir. ${ }^{12}$

Bahâ Saîd’in, Alevîlik-Bektaşîlik ve Nusayrîlik hakkında yaptığ1 çalışmaları; "Türkiye'de Alevî Zümreleri: Tekke Alevîliği-İctimâ̂ Alevîlik", "Sûfiyân Süreği: Kızılbaş Meydanı I-II", "Anadolu'da Alevî Zümreleri: Tahtact, Çepni, Hardal Türkmenleri Yahut Yan Batır Zümresi", "Anadolu'da Gizli Mabetlerden: Nusayrîler ve Esrar-ı Mezhebiyeleri", "Sözün Doğrusu" ve "Bektaşîler I-III", basslığı adıyla seri olarak, 1926-1927 yılları arasinda Türk Yurdu dergisinin IV. ve V. ciltlerinde yayınlanmıştır. Bu çalışmalar hakkında aşağıda bilgi verilecektir.

\section{Bahâ Saîd Bey'in Hayatı, Kişiliği ve Eserleri}

\section{1. Hayati (1882-1939)}

Bahâ Saîd Bey, Osmanlı'nın son Cumhuriyet'in ilk yıllarında yaşayan millî kahramanlardandır. Bazı kaynaklar onun 1882'de Çanakkale'nin Biga ilçesinde doğduğunu belirtirken ${ }^{13}$ bazıları ise Dağıstan doğumlu olduğunu ve gençlik yıllarında Türkiye'ye geldiğini kaydeder. ${ }^{14}$ Bahâ Saîd, eğitim ve öğretimini Kurmay Yüzbaş1 rütbesiyle tamamladı. Aynı rütbeyle ordu saflarına katıld1. Ancak komutanlarıyla uyum sağlamadığı için kısa sürede emekliye sevk edilerek ordudan ayrıld1. ${ }^{15}$ Meşrutiyet'ten Cumhuriyet'in ilanına kadar geçen sürede, Millî Talim ve Terbiye Cemiyeti, Türk Ocağ1, Karakol Cemiyeti, Milli Kongre ve İttihat Terakki Cemiyeti gibi politika, sanat ve kültür kurumlarında aktif görevler üstlendi. ${ }^{16}$ Vatanı ve milleti için herhangi bir şahsi çıkar gözetmeksizin en ön saflarda çetin ve tehlikeli birçok hizmetlerde bulundu. ${ }^{17}$

12 Sarısır, "Alevî-Bektaşî Zümreler Hakkında Yapılan İlk Araştırmalar", 424.

13 Halide Özüdoğru Erdoğan, "Bahâ Saîd Bey", Ahi Ansiklopedisi, (Ankara: Gümrük ve Ticaret Bakanlığı, 2016), 1: 285.

14 Tevetoğlu, "Millî Mücadele Kahramanlarından: Bahâ Saîd Bey", 208.

15 Tevetoğlu'nun kanaatine göre onun kısa sürede ordudan çıkarılması, disipline uymayan haşarı bir öğrenci izlenimi vermesinden kaynaklanmıştır. Bkz. Tevetoğlu, "Millî Mücadele Kahramanlarından: Bahâ Saîd Bey", 209; Bahâ Saîd, Türkiye'de Alevî-Bektaşî, Ahî ve Nusayrî Zümreleri, 2; Erdoğan, "Bahâ Saîd Bey", 1: 285.

$16 \mathrm{Bu}$ cemiyetler hakkında geniş bilgi için bkz.Tevetoğlu, "Millî Mücadele Kahramanlarından: Bahâ Saîd Bey", 212-221; Bahâ Saîd, Türkiye'de AlevîBektaşî, Ahî ve Nusayrî Zümreleri, 2; Erdoğan, "Bahâ Saîd Bey", 1: 285.

17 Tevetoğlu, "Millî Mücadele Kahramanlarından: Bahâ Saîd Bey", 207; İsmail Görkem, "Türk Folklor Araștırma Tarihinde Millî Talim ve Terbiye Cemiyeti ve Bahâ Saîd Bey’in Yeri”, Uluslararası Beşeri Bilimler ve Eğitim Dergisi, 5/10 (79 Mayıs 1992), 49. 
Bahâ Saîd, II. Meşrutiyet'in ilânına kadar bir süre Kahire'de kaldı. Orada süsleme sanatı ile ilgili eğitim gördükten sonra camilerin süsleme isslerini yaptı. O, Meşrutiyet'in ilanından sonra İstanbul'a döndü ve bir yazıhane açarak ticaretle meşgul oldu. Ömrünün son yıllarını İstanbul'da hem resim hem de okuyup araştırma yaparak geçirdi. ${ }^{18}$ Çağdaş bir yapıya haiz olan Bahâ Saîd, birçok yabancı dile vakıft1. ${ }^{19}$

Kurtuluş harbinin yaşandığı dönemde Atatürk tarafından görevlendirilen Bahâ Saîd, Anadolu'yu gezerek halkı örgütlemiştir. Cumhuriyet'in ilanından sonra vatanı adım adım dolaşarak Türk kabilelerinin hasseten de ülkenin doğusunda yaşayan toplulukların dinî ve kültürel yönlerini araștırmayı kendisine görev saydı. ${ }^{20}$ Ömrünün son yıllarını İstanbul'da geçiren Bahâ Saîd, 16 Ekim 1939'da kalp krizi sebebiyle vefat etti ve Merkezefendi'deki aile kabristanına defnedildi. ${ }^{21}$

Bahâ Saîd, Türk Ocağı tarafından düzenlenen çeşitli etkinliklere katıldı. Çizdiği resimlerle Türk Ocağı'na maddî destek sağladı. Türk Yurdu dergisinin bir sayısında "Temüçin" takma ismiyle "Türk Kardaşlarıma" hitaben, "Sözün Doğrusu" şiiri ile millî hislerini ve görüşlerini açıkladi. ${ }^{22}$

Hiç evlilik yapmayan Bahâ Saîd'in bir erkek kardeşi ve akrabalarından dayısının kızı Adâlet Hanım ile dayısının oğlu Feyzi Ergin vardır. En yakın arkadaşları arasında ise Mustafa Şekip ile Hilmi Ziya Ülken bulunmaktadir. ${ }^{23}$

Anadolu'daki Alevî-Bektaşî inancı hakkında önemli bilgileri olan Elazığ'lı Cafer Yağdıran'ın 1965'te yazdığ mektubunda onun ismini "Bahauddîn Seyyid" şeklinde kaydetmiştir. ${ }^{24}$ Bahâ Saîd hakkında

18 Tevetoğlu, "Millî Mücadele Kahramanlarından: Bahâ Saîd Bey", 209; Erdoğan, "Bahâ Saîd Bey", 1: 285.

19 Yeni Sabah, "Kahraman Bahâ Saîd Öldü", Yeni Sabah Gazetesi 2/527 (19 İlk Teşrîn 1939), 5; Tevetoğlu, "Millî Mücadele Kahramanlarından: Bahâ Saîd Bey”, 212; Bahâ Saîd, Türkiye'de Alevî-Bektaşî, Ahî ve Nusayrî Zümreleri, 3; Erdoğan, "Bahâ Saîd Bey", 1: 285.

20 Tevetoğlu, "Millî Mücadele Kahramanlarından: Bahâ Saîd Bey", 210-211; Erdoğan, "Bahâ Saîd Bey", 1: 285; Nejat Birdoğan, İttihat Terakki'nin AlevîlikBektaşîlik Araştırması (Bahâ Saîd Bey), (İstanbul: Berfin Yayınları, 1999), 10.

21 Bahâ Saîd, Türkiye'de Alevî̀-Bektaşî, Ahî ve Nusayrî Zümreleri, 3; Fethi Tevetoğlu'nun tesbitlerine göre ise Bahâ Saîd Bey, 1935 veya 1936 yılında vefat etmiştir. Bkz. Fethi Tevetoğlu, Türkiye'de Sosyalist ve Kominist Faâliyetler (1910-1960), Ankara 1967, 282.

22 Tevetoğlu, "Millî Mücadele Kahramanlarından: Bahâ Saîd Bey", 214.

23 Tevetoğlu, "Millî Mücadele Kahramanlarından: Bahâ Saîd Bey", 209-210.

24 Bahâ Saîd, Türkiye'de Alevî-Bektaşî, Ahî ve Nusayrî Zümreleri, 4. 
çalışması olan İsmail Görkem'e göre Bahâ Saîd, böyle bir ismi Doğudaki Alevî toplulukları ile daha sağlıklı bir diyalog kurabilmek maksadiyla kullanmış olabilir. 25

Bedri Noyan Bahâ Saîd'i "Bey Baba" şeklinde nitelendirmektedir. ${ }^{26}$ Onun bu vasıflandırmasına göre Bahâ Saîd'in Şiî hatta Alevî olmadığı ileri sürülür. ${ }^{27}$ Çünkü Bedri Noyan'ın ona uygun gördüğü vasıfta "Dede" ünvanı bulunmamaktadır. "Baba" ünvanı Çelebi ve Ocakzade'den sonra gelmekte ve Hacı Bektaş'in yolundan gidenlere başka bir deyişle "yol evlatları"na isim olarak verilmektedir. ${ }^{28}$

Kurtuluş savaşının isimsiz yiğitleri gibi Bahâ Saîd'in de şahsiyeti, hayatı ve çalışmaları ile ilgili pek fazla malumat bulunmamaktadır. Türkiye'de yayınlanmış olan kaynaklarda onun hayat hikayesi hakkında yeterli malumata rastlamanın çok zor olduğu belirtilmektedir. ${ }^{29}$ Bahâ Saîd, hakkında bugüne kadar yayınlanmış ilk araştırma 1989 yılında Atatürk Araştırma Merkezi Dergisi'ndeki Ferit Tevetoğlu'na ait bir makaledir. Bahâ Saîd'le ilgili bir çalışma da onun "Türkiye'de Alevî̀-Bektaşî, Ahî ve Nusayrî Zümreleri" adlı eserinin girișini yazan ve yayına hazırlayan İsmail Görkem tarafından yapılmıştır. Araştırmamızda en çok Görkem'in bu çalışmasından yararlanılmıştır.

\section{2. Kişiliği}

Bahâ Saîd, öldükten sonra onun kişiliğine ait özelliklerini 19 İlkteşrîn 1939'da Yeni Sabah gazetesinde imzasız olarak yayınlanan sayfa 5 ve 7'de "Kahraman Bahâ Saîd öldü" başlığ1 altındaki bilgilerden öğreniyoruz. Bu bilgilerde Bahâ Saîd, özetle şu şekilde tanıtılmıştır: "Bugünkü neslin, gençliğin tanıyamadığı millî kahramanlardan birisidir. İsmi Meşrutiyet İnkılâbına karışan Bahâ Saîd, Birinci Dünya Savaşı'ndaki fedakarca faaliyetleri, Türkistan, Afganistan ve Kafkaslar'daki hayrete şayan maceraları ile tarihin öz malı olmuş bir şahsiyettir." 30

"O, bütün enerjisini, zekasını memleketine hasretmiş, hayatını yurduna adamış, şöhret olmaktan sürekli sakınmış, feragat ve tevazuyu kendine şiar edinmiştir. Çok sevdiği milletinin selameti ve menfaati söz konusu olduğu her zaman Bahâ Saîd, hiçbir tehlikeden,

25 Bahâ Saîd, Türkiye'de Alevî-Bektaşî, Ahî ve Nusayrî Zümreleri, 4.

26 Bahâ Saîd, Türkiye'de Alevî-Bektaşî, Ahî ve Nusayrî Zümreleri, 4.

27 Bahâ Saîd, Türkiye'de Alevî-Bektaşî, Ahî ve Nusayrî Zümreleri, 4.

28 Bahâ Saîd, Türkiye'de Alevî̀-Bektaşî, Ahî ve Nusayrî Zümreleri, 4, Esat Korkmaz, Ansiklopedik Alevîlik Bektaşîlik Terimleri Sözlüğü, (İstanbul: Ant Yayınları 2. Baskı 1994), 89-90.

29 Bahâ Saîd, Türkiye'de Alevî-Bektaşî, Ahî ve Nusayrî Zümreleri, 1.

30 Yeni Sabah, "Kahraman Bahâ Saîd Öldü”, 2/527 (19 İlk Teşrîn 1939), 5. 
ve fedakarlıktan kaçınmamıştır. Her millî teşebbüste daima ileri atılmış ve herkesten çok çalışmıştır. Mütareke'nin en zor günlerinde, mukadderat karşısında herkesin, ümitsizliğe kapıldığı bir zamanda Bahâ Saîd, metanetini ve itidalini koruyarak Türk milletine taze bir can ve kan olmuş, yepyeni bir azim ve iman vermeye çalışmıştır." 31 Kısaca Bahâ Saîd hakkında, seçkin kişiliğiyle hayatını ülkesine ve milletine vakfetmiş samimi bir milliyetçi kişiliğe sahip birisidir denebilir.

Bahâ Saîd hakkında ilk olarak makale yazan ve onu sağ iken yakından tanıyan Fethi Tevetoğlunun onun hakkındaki görüşü şu şekilde olmuştur: “...Bahâ Saîd, ön saflarda ağır ve riskli pek çok görevler yapmış, bunu asla şahsı adına bir menfaat için yapmamıştır. Güzide şahsiyetiyle yaşamını ülkesine ve milletine vakfetmiş hakiki bir milliyetçi ve ülkücü örneği veren Bahâ Saîd, ömrü süresince tarihimizin "feragat faslının meşhur, menfaat faslının meçhul" kimselerden birisidir. Milli mücadele tarihimizin diğer isimsiz kahramanları gibi, Bahâ Saîd'in de şahsiyeti, hayatı ve görevleriyle eserleri ile ilgili çok az malumat bulunmaktadır."32

\section{3. Eserleri}

İttihat ve Terakki Cemiyetince; "Anadolu'daki toplumsal zümreler" ile "Anadolu Sosyolojisinin" araştırılması görevi verilen ${ }^{33}$ Bahâ Saîd'in, Anadolu'daki zümreler hakkında incelemeler yaptığı, Hacı Bektaş Velî ve Mevlânâ hakkında ise yayınlanmamış bir eser kaleme aldığı kaydedilmektedir. ${ }^{34}$ Bahâ Saîd, bu araştırmaları neticesindeki yazılarının bir kısmını neşrettiğini, bir parçasını yayınlamadığını, önemli bir kısmının ise arkadaşı Hilmi Ziya Ülken'de olduğunu belirtmiştir. ${ }^{35}$ Ayrıca İşişleri Bakanlığındaki klasörlerinin çalınıp kitap şekline getirilmesinden yakındığı bildirilir. ${ }^{36}$ Ancak bu kitabın ismi bilinmemektedir.

Bahâ Saîd'in Türk Yurdu'nda yayınlanan makaleleri, Türkiye'de Alevî toplulukları içinde yapılmış en akademik yöntemlere dayanan araştırmalarındandır. ${ }^{37}$ Dayızâdesi Feyzi Ergin ile kızkardeşi Atâlet

31 Yeni Sabah, “Kahraman Bahâ Saîd Öldü”, 2/527 (19 İlk Teşrîn 1939), 5.

32 Tevetoğlu, "Millî Mücadele Kahramanlarından: Bahâ Saîd Bey", 207.

33 Bahâ Saîd, Türkiye’de Alevî̀-Bektaşî, Ahî ve Nusayrî Zümreleri, 22.

34 Tevetoğlu, "Millî Mücadele Kahramanlarından: Bahâ Saîd Bey", 210.

35 Hilmi Ziya Ülken de Bahâ Saîd'in çalışmalarının bir kısmının kendisinde yayınlanmamış halde bulunduğunu ifade etmektedir. Bkz. Ülken, Türkiye'de Çağdaş Düşünce Tarihi, sayfa 257'de 302. dipnot.

36 Tevetoğlu, "Millî Mücadele Kahramanlarından: Bahâ Saîd Bey", 211; Bahâ Saîd, Türkiye'de Alevî̀-Bektaşî, Ahî ve Nusayrî Zümreleri, 22.

37 Fethi Tevetoğlu, “Türkçü Dergiler III”, Türk Kültürü, 26/299 (Mart 1988), 146155 
Hanım'ın verdikleri bilgilere göre o, Kırşehir ve Konya'da Bektaşîlik ve Mevlevîlik üzerine bilimsel araştırmalar ve tetkikler yapmıştır. Ayrıca onun Mevlâna ve Hacı Bektaș Velî hakkında yayınlanmamıș bir kitabının bulunduğu belirtilir. ${ }^{38}$ Bunların dişında onun neşredilen iki eseri bulunmaktadır. Bu iki eser hakkında aşağıda kısa bilgiler verilecektir.

\section{3. 1. Anadolu'daki Alevî Bektașî, Ahî ve Nusayrî Zümreleri}

Bahâ Saîd'in sağlığında hazırladığı ancak çeşitli nedenlerle yayınlayamadığı bir eseridir. Bahâ Saîd Bey'in notları ile birlikte çalışmalarının tamamı İsmail Görkem tarafından hazırlanarak bir kitap halinde neşredilmiştir. Söz konusu kitap ilk defa 2000 yllında Kültür Bakanlığı tarafından basılmıştır.

\section{3. 2. Şehîdü'1-Hak Zeki Bey}

$\mathrm{Bu}$ eser, broşür halinde yayınlanmış bir protesto yazısının birinci bölümünü oluşturmaktadır. 1329 tarihinde İstanbul'da Hikmet Matbaası tarafindan neşredilmiş 78 sayfalık bir eserdir. Bu eser, onun çok değer verdiği arkadaşı Zeki Bey'in İttihat ve Terakki mensuplarınca katledilmesi hadisesini ele almaktadır. Ayrıca bu eserde, cinayeti düzenleyenler protesto edilmekte, şehit edilen Zeki Bey'in hal tercümesi ve bu konuyla ilgili bilgi ve belgeler ele alınmaktadır. $\mathrm{Bu}$ bilgiler eserin birinci kısmını oluşturmaktadır ancak ikinci kısmına ulaşılamadığı belirtilmektedir. ${ }^{39}$

\section{3. 3. Makaleleri}

Bahâ Saîd'in başta Türk Yurdu mecmuası olmak üzere Muhibbân, Memleket ve Meslek gibi gazete ve dergilerde yayınlanmıss makaleleri bulunmaktadır. Tespit edilebildiği kadarıyla onun makalelerini şu şekilde sıralayabiliriz:

\section{3. 3. 1. Türk Yurdu'nda Yayınlanan Makaleleri}

Bahâ Saîd, İttihat ve Terakki'nin kurucularından Sadrazam Talat Paşa tarafından 1914-1915 yıllarında, Anadolu'daki Alevî-Bektaşî zümreleri hakkında ayrıntılı bir araştırma ve inceleme yapmak üzere Anadolu'ya gönderilmiştir. ${ }^{40}$ Anadolu'daki toplulukları yerinde tetkîk ederek araştırmıştır. Bahâ Saîd, uzun bir çalışmanın mahsulü olan Alevîlik-Bektaşîlikle ilgili araştırmalarını tamamladıktan on yıl sonra 1926-1927 y1llarında Türk Yurdu dergisinin IV. ve V. ciltlerinde

38 Tevetoğlu, "Millî Mücadele Kahramanlarından: Bahâ Saîd Bey", 210.

39 Bkz. Tevetoğlu, "Millî Mücadele Kahramanlarından: Bahâ Saîd Bey", 212-213.

40 Ülken, Türkiye'de Çağdaş Düşünce Tarihi, sayfa 257'de 302. dipnot; Enver Behnan Şapolyo, Mezhepler ve Tarikatlar Tarihi, (İstanbul: Türkiye Yayınları, 1964), 331. 
neşretme imkanını bulmuştur. ${ }^{41}$ Ayrıca onun Türk Yurdu'nda kendi imzasıyla Bektaşîliğe ilişkin incelemeleri ve "Temüçin" müstear ismiyle de bir şiiri bulunmaktadır. Onun söz konusu zümreler hakkındaki araştırmaları Türk Yurdu'nda şu başlıklar altında yayınlanmıştır:

- "Türkiye'de Alevî Zümreleri: Tekke Alevîliği-İçtimaî Alevîlik", Türk Yurdu, 4/21, Eylül 1926, 193-210.

- "Sûfiyân Süreği: Kızılbaş Meydanı", Türk Yurdu, Teşrin-i Evvel 1926, 4/22, 325-360.

- "Sûfiyân Süreği: Kızılbaş Meydan1, Düşkünlük", Türk Yurdu, 4/23, Teşrin-i Sani 1926, 404-421.

- "Anadolu'da Alevî Zümreleri: Tahtacı, Çepni, Hardal Türkmenleri Yahut Yan Batır Zümresi”, Türk Yurdu, 4/24, Kanun-i Evvel 1926, 481-492.

- "Bektaşiler-I", Türk Yurdu, 5/26, Şubat 1927, 128-150.

- "Bektaşiler-II", Türk Yurdu, 5/27, Mart 1927, 196-216.

- "Bektaşiler-III", Türk Yurdu, 5/28, Nisan 192, 305-341.

- "Anadolu'da Gizli Mabetlerden: Nusayrîler ve Esrar-1 Mezhebiyeleri”, Türk Yurdu, 5/25, Kanun-i Sani 1927, 6-27.

- "Sözün Doğrusu", Türk Yurdu, 1/16, 14 Haziran 1328, 473-474.

\section{3. 3. 2. Muhibbân Mecmuası'nda Yayınlanan Makaleleri}

- "Tasavvuf ve Hür Mezhepler", Muhibbân, 3/4, 30 Kanunusani $1335,1-2$.

- "Ehl-i Hak ve Atam Gök Anam, Yer", Muhibbân, 3/5, 1 Mayıs $1335,2-3$.

\section{3. 3. 3. Memleket Gazetesi'nde Yayınlanan Makaleleri}

- "Memleketin İç Yüzü: Anadolu'da Gizli Mabetler-I", Memleket Gazetesi, no: 2, Cemâziyelevvel 1337/11 Şubat 1335 Salı/1919.

- "Memleketin İç Yüzü: Anadolu'da Gizli Mabetler-II", Memleket Gazetesi, no: 18, 26 Cemâziyelevvel 1337/ 27 Şubat 1335/1919.

- "Memleketin İç Yüzü: Anadolu'da Gizli Mabetler-III", Memleket Gazetesi, no: 46, 24 Cemâziyelâhir 1337/ 27 Mart 1335 Perşembe/ 1919.

\footnotetext{
41 Yeni Sabah, "Kahraman Bahâ Saîd Öldü", 2/527 (19 İlk Teşrîn 1939), 5-7;
} Birdoğan, İttihat Terakki’nin Alevîlik-Bektaşîlik Araştırması, 9. 
- "Memleketin İç Yüzü: Anadolu'da Gizli Mabetler-IV", Memleket Gazetesi, no: 48, 26 Cemâziyelâhir 1337/ 29 Mart 1335 Cumartesi/ 1919.

- "Memleketin İç Yüzü: Anadolu'da Gizli Mabetler-V", Memleket Gazetesi, no: 71, 20 Recep 1337/ 21 Nisan 1335 Pazartesi/1919.

- "Memleketin İç Yüzü: Anadolu'da Gizli Mabetler-VI", Memleket Gazetesi, no: 72, 21 Recep 1337/ 22 Nisan 1335 Sal1/1919.42

\section{3. 3. 4. Meslek Gazetesi'nde Yayınlanan Yazıları}

- "Eski Türkiye'de İş Teşkilâtı/İttihat ve Terakki Tarafından Evvelce Ankara ve Havalisinde Yaptırılan Tetkikata Göre Ahîlere Dair Elde Edilmiş Olan Malûmat-I", Meslek Gazetesi, sene.1, no: 19, 12 Nisan 1325, 5.

- "Eski Türkiye'de İş Teşkilâtı-II", Meslek Gazetesi, sene.1, no: 20, 28 Nisan 1325, 8.

- "Eski Türkiye'de İş Teşkilâtı/Esnaf Arasında Şed Kuşanmak, Kadıların Tasdikleri, Ketebeye Hürmet, Esnaf Beyninde Ceza-III”, Meslek Gazetesi, sene.1, no: 21, 5 Mayıs 1325, 8.

- "Eski Türkiye'de İș Teşkilâtı/Kavaf, Dikici, Bostancı ve Bu Kollar Arasında Teşkilât-IV", Meslek Gazetesi, sene.1, no: 22, 12 Mayıs 1325, 5.

Bunların dişında Bahâ Saîd'in;

- "Anadolu'da İctimâî Zümreler ve Anadolu İctimâiyatı", Millî Talîm ve Terbiye Mecmuas1, no: 5, Ağustos 1334/1918, 18-32 ile

- Ahali Gazetesi (Samsun) yıl 22, say1: 847, 29 Ekim 1933 Pazar, s. 3'te makaleleri bulunmaktadir. ${ }^{43}$

Ayrıca Sebîlürreşâd dergisinde ise Rusya Türkleriyle ilgili haberler ve Türkçülük üzerine imzasız yazılar yazdığı belirtilmektedir. ${ }^{44}$

2. Anadolu'daki Alevî-Bektaşî ve Nusayrî Caimasına İlişkin Araştırmaları

\section{1. Anadolu'daki Alevî-Bektaşî Camiasına İlişkin}

\section{Araștırmaları}

Sadrazam Talat Paşa, Ziya Gökalp’in tavsiyesi üzerine Bahâ Saîd'i, Anadolu'daki tarikatları, Alevî-Bektaşî zümrelerini, Hardal Türkmenlerini, Çepni ve Tahtacıları yakından incelemek üzere

42 Bahâ Saîd, Türkiye'de Alevî-Bektaşî, Ahî ve Nusayrî Zümreleri, 51-52.

43 Bahâ Saîd'in yayınları hakkında geniş bilhi için bkz. Türkiye'de Alevî-Bektaşî, Ahî ve Nusayrî Zümreleri, 22-42.

44 Tevetoğlu, "Millî Mücadele Kahramanlarından: Bahâ Saîd Bey", 209. 
görevlendirmiştir. ${ }^{45}$ Bahâ Saîd, ömrünün neredeyse yarısını Anadolu'daki Ahîleri, Nusayrîleri ve Alevî-Bektaşi topluluklarını tetkik etmekle geçirmiștir. Anadolu'daki misyonerlerin, Alevî-Bektaşî zümrelerinin "Hıristiyan dönmesi" şeklindeki girișimlerine karşın Bahâ Saîd, onlarla ilgili çalışmayı gerekli görmüştür. ${ }^{46}$ Hatta bu tür çalışmalarından dolayı bir mecmua tarafından ona, "yıkılan Türk Ocağı'nın dinsiz çocukları șimdi de Kızılbaşlık propogandası yapıyor" şeklinde karş1lık verdiği ifade edilir. ${ }^{47}$ Onun konuyla ilgili yaptığ araştırmalar çeşitli dergilerde yayınlanmıștır. Biz de konu bütünlüğünü korumak açısından onun araştırmalarını yayınlanış sırasına göre değerlendirmeye çalıştık.

Muhibbân mecmuasında yayınlanan "Tasavvuf ve Hür Mezhepler" adlı makalesinde Baha Saîd, tasavvufun İslâm tarihindeki öneminin ve etkisinin bariz bir şekilde ortada olduğunu vurgular. Ona göre Dürzîler, Nusayrîler, İbâdîler, Batınîler, Yezidîler ve özellikle Anadolu'nun yarısını oluşturan Bektaşî ve Kızılbaş zümreleri sosyal hayat oluşturabilen hür mezheplerden sayllmaktadır. Bunlara mukabil Nakşîlik, Kadirîlik ve Mevlevîlik gibi tarikatler birer sosyal hayat oluşturamamıștır. Safevîlik, saltanata dayandığı halde Bektaşilik gibi bir sosyal hayat oluşturmayı başaramamıștır. Ona göre Anadolu'da yaşayan Türklerin bir kısmını bir araya getiren Alevî camiası, toplumun birlik ve beraberliği açısından örnek bir tavır sergilemiştir. Bu Türk zümreleri hür mezhepler arasında çağdaş bir toplumsal yaşam sergilemiștir. ${ }^{48}$ Bahâ Saîd'in araștırmalarına baktığımızda ilk defa bu makalesinde Alevîlerden bahsettiği görülmektedir.

Bahâ Saîd, Muhibbân mecmuasında yayınlanan "Ehl-i Hak ve Atam Gök, Anam Yer" adlı kısa makalesinde, Bektaşîlik öğretilerinin felsefî niteliklerini araştırmış ve teorik yorumlar yapmıştır. Ayrıca Bektaşî felsefesine göre Hakk'in farklı tanımlarına yer vermiştir. Ona göre, "Hakk, öyle bir kelime ki, medlûlü, insanlık için ebediyen meçhul kalmış ve yine öyle kalacaktır." 49

Bahâ Saîd, Millî Talìm ve Terbiye Mecmuası'nda neşredilen “Anadolu'da İctimâî̉ Zümreler ve Anadolu İctimâiyatı"adlı makalesinde Türk aile yapısının şekillemesinde Maniheizm, Mazdeizm, Taoizm ve

45 Tevetoğlu, "Millî Mücadele Kahramanlarından: Bahâ Saîd Bey", 209; Bahâ Saîd, Türkiye'de Alevî̀-Bektaşî, Ahî ve Nusayrî Zümreleri, XI.

46 Bahâ Saîd, Türkiye'de Alevî-Bektaşî, Ahî ve Nusayrî Zümreleri Giriş, XI-XII.

47 Bahâ Saîd, Türkiye'de Alevî̀-Bektaşî, Ahî ve Nusayrî Zümreleri Giriş, XI-XII.

48 Baha Saîd, "Tasavvuf ve Hür Mezhepler", Muhibbân, 3/4 (30 Kanunusani 1335), 1-2.

49 Bahâ Saîd, "Ehl-i Hak ve Atam Gök Anam, Yer", Muhibbân, $3 / 5$ (1 Mayıs 1335), 2-3. 
Budizm'in tesirleri olduğunu belirtmektedir. O, ideolojik ve kuramsal bir metotla anlattığ1 "Atam Gök, Anam Yer" ülküsünü Orhun Kitabeleri'nden esinlenerek güvenilir kaynaklara dayandırmakta ve bunu Alevî ve Bektașîlerle irtibatlandırmaktadır.50 Ona göre Hacı Bektaş Velî, Türklerin ilkel dinleri ile Maniheizm'i İslâmiyet'le uzlaştırmada başarılı olan zeki bir kişidir. Bektaşî âyinleri Yavuz dönemine kadar asliyetini asla kaybetmemiștir. Bektaşilik Yavuz zamanında Balım Sultan aracılığıyla bir inkılâb aşaması geçirmiş, Anadolu'da kalıcı bir iz bırakmıss ve birakmaya da devam edecektir. Bahâ Saîd, Balım Sultan İnkılâbına tâbi olmayan muhafazakarları Kızılbaş olarak nitelendirmiştir. Bektaşîler gibi onlar da "yer anam, gök atam" prensibini benimsemişlerdir. Ona göre Bektaşîlerin veya Anadolu Kızılbaşların sosyalist ve kominist hayatları, marifet makamını anlayış şekillerine göre değişmektedir. Ayrıca bütün tasavvufî yollar asliyetini kaybetmelerine rağmen Bahâ Saîd, Bektaşîler ve Kızılbaş zümreleri arasında devam eden eski Türk dini, ocak geleneği, kadınlara olan serbestlik, saz ve söze atfedilen diğer eski Türk telakkileri gibi benzerlikleri tespit etmiștir. ${ }^{51}$

Bahâ Saîd'e göre Türklerin Anadolu'ya yerleşmesi İslâm'dan öncesine ve sonrasina dayanır. Osmanlilar Anadolu'ya yerleşmesinden sonra millî bir mezhep olan Bektaşîlik doğmuştur. Onun Bektaşîliğin doğuşunu Türklerin Anadolu'ya yerleşmesine bağladığ1 ve Bektaşîliği "millî bir mezhep" olarak gördüğü şu ifadelerinden anlașilmaktadır: "Osmanlıların Anadolu'da kökleşmesiyle millî bir mezhep" oluşmuştu. Bu mezhep de Bektaşîlik!"52 Ayrıca onun tespitlerine göre Baba İlyas, "Anadolu'daki ilk Türkçü" kişilerden birisidir. ${ }^{53}$

Bahâ Saîd, araştırmasında Ahîlerin Bektaşîlerden etkilendiğini ve aralarında kuvvetli bir bağın oluştuğunu vurgular. Âşık Paşa, Ahî Evren, Şeyh Süleyman ve Hac1 Bektaş'in bir fikrin müctehitleri olduğunu belirterek bu görüşün temsilcileri olarak telakki ettiği Kırşehir'deki Caka Bey Medresesi ile Konya'nın Karatay Medresesi'nin birbirleriyle rekabet ettiklerini anlatır. Karatay Medresesi'nin Fars felsefesi ve ictihadı ile meşgul olurken, Caka Bey Medresesi'nin Âşık Paşa'nın Garipnamesi'ni okutmakla Türk diline sahip çıktığına dikkat çeker. Ancak bu medreseye gerekli ilginin gösterilmemesinden de yakınmaktadır. ${ }^{54}$

50 Bkz. Bahâ Saîd, "Anadolu'da İctimâî Zümreler ve Anadolu İctimâiyatı", Millî Talìm ve Terbiye Mecmuası, 5, (Ağustos 1334/1918), 28-30.

51 Bahâ Saîd, “Anadolu'da İctimâî Zümreler ve Anadolu İctimâiyatı”, 29-30.

52 Bahâ Saîd, "Anadolu'da İctimâî Zümreler ve Anadolu İctimâiyatı", 30.

53 Bahâ Saîd, "Anadolu'da İctimâî Zümreler ve Anadolu İctimâiyatı", 31.

54 Bahâ Saîd, "Anadolu'da İctimâî Zümreler ve Anadolu İctimâiyatı”, 31. 
Ona göre Bektaşiliğin bozulması Kanunî zamanında başlamıştır. Ancak mezhep ve felsefesiyle millî varlığını hicrî 920 tarihine kadar devam ettirebilmiştir. Bu tarihten sonra Bektaşîliğe Mazdekîlik yani Mazdehizim dahil olmus, böylece temel yapısını koruyarak, iman ve itikatta millî vasfiyetini kaybetmiştir. O, gerçek Bektaşîliğin çöküşünü üç eski yüzyıla havale etmektedir. Ona göre, "Bektaşîlik Türkiye'nin hayat ve memâtıyla hem-hâl olmuştur. Bu ocağın, sosyal yapı üzerindeki tesirleri anlaşılmadıkşa, sadece Türklük değil aynı zamanda Türkiye'de anlaşılamayacaktır."55

Müellif makalesinde Bektaşîlik hakkında yazılan eserlerin azlığından yakınmakta bu konuda ilmî değeri olan Kitâb-ı Makalât, Garbnâme ve Velâyetnâme-i Hacı Bektaş Velî gibi bu üç kıymetli tarihi eseri ön plana çıkarmaktadır. Ona göre bu eserler Bektaşîliğin ne demek olduğunu açıkça anlatmaktadır. Bahâ Saîd'in Bektaşîlik açısından önemli bulduğu bu tarihi eserleri Hacı Bektaş Kütüphanesi'nde görerek incelediği anlașılmaktadır. Bahâ Saîd'e göre bu tarihi eserler dişında Bektaşîlik ile ilgili birkaç daha eserin olma ihtimali söz konusudur ancak bu eserlerin Balım Sultan İnkılâbından sonraya ait olmasından dolayı ilmî bir değeri bulunmaktadır. Bu konudaki eserlerin ilmî bir değer taşıması için Balım Sultan'dan önce yazılması gerekmeketedir. ${ }^{56}$

Bahâ Saîd, bu eserlerden hareketle Bektaşîliği eski ve yeni olmak üzere iki döneme ayırmıştır. Ona göre Bektaşilik bu dönemlerde Anadolu'da gerçek eserler bırakmıştır. Bu konuda Kızılbaş Sürekleri'ni örnek olarak göstermiştir. Ona göre, Çepnîler ve Tahtacilar, eski Sürek'ten daha eskidirler ve Bektaşîliği yenilik diyerek reddetmişlerdir. ${ }^{57}$

Memleket gazetesinde seri şekilde yayınlanan "Memleketin İçyüzü: Anadolu'da Gizli Mabetler" adlı yazılarında Bahâ Saîd, Türkiye'deki mezhep taraftarlarını, İbâdî, Yezîdî, İsmaîlî, Tâvusî, Sürek, Sûfiyân, Tahtacı, Bektaşî ve Kızılbaş fırkaları biçiminde ele almaktadır. Ona göre âyinlerini gizli yapan bu mezheplerin hiçbirisinin âyin ve erkanı birbirine benzememektedir. O, gizli mezhepleri Turanî ve Sami asıllı şeklinde ikiye ayırmaktadır. Turanî inanç mensuplarında vicdan, Sami inanç mensuplarında ise iman asıldır. Bütün bu mezhepler, İslâm kisvesi ile süslediği akidelerinin esasını hakiki İslâm unsurlarıyla birleştiğine inanmaktadırlar. Dolayısıyla da Bahâ Saîd'e göre Dürzî, Nusayrî, Kızılbaş ve Bektaşî gibi mezheplerin yegane kaynağı $\mathrm{Hz}$. Ali olduğundan dolayı bu ismi zikredilen mezheplerin

55 Bahâ Saîd, "Anadolu'da İctimâî Zümreler ve Anadolu İctimâiyatı", 31.

56 Bahâ Saîd, "Anadolu'da İctimâî Zümreler ve Anadolu İctimâiyatı", 31-32.

57 Bahâ Saîd, “Anadolu'da İctimâî Zümreler ve Anadolu İctimâiyatı”, 32. 
hepsine birden Alevî demek daha doğrudur. Ancak dinî tarih bunu inkar etmiş olsa da Bahâ Saîd'e göre bir tek Muhammet ümmeti olduğunu Ali ümmeti olmadığını 1srarla söyleyenler Ehl-i Sünnet ve Mu'tezile şeklinde ayrılmışlar, üstelik birbirlerine sövmüş, saymışlar, zem ve tel'in etmisslerdir. ${ }^{58}$

Memleket gazetesinde yayınlanan 'Memleketin İcyüzü: Anadolu'da Gizli Mabetler" adlı ikinci makalesinde Bahâ Saîd, Ege ve Akdeniz sahillerinde varlıklarını sürdüren Tahtacıların "Sarı Kız Mabedi ile ilgili düzenlenen "Yan Yatır Süreği"ni anlatmakla birlikte Tahtacıların özelliklerinden, yaşam tarzlarından ve bu bölgelerdeki nüfuslarından bahsetmektedir. Tahtacıların mezhebi teşkilatları ve "Sarı Kız Süreği" hakkında birtakım bilgiler vermekte ve ayrıca "Sarı kız Efsanesi"nin tarihsel ve mitolojik menşelerini araştırmaktadır. ${ }^{59} \mathrm{Bu}$ makaleyi genel olarak incelediğimizde Bahâ Saîd’in Tahtacılar hakkında gözleme dayalı bir saha araştırması yaptığı anlassılmaktadır.

Memleket gazetesinde yayınlanan üçüncü makalesinde Bahâ Saîd, o dönemin şartlarına göre ülkenin o günkü ve gelecekteki durumu ile ilgili bazı yorumlarda bulunmuştur. Millî birlik ve beraberliğe dikkat çeken Bahâ Saîd, bu birliği Türkiye düşmanlarının ve yerli issbirlikçilerinin doğuda yaşayan Ermeni, Sünnî, Şiî, Kızılbaş Yezîdî, Sûfiyân, Kürt, Nastûrî gibi mezhepler ve milletler üzerinden Türk birliğini bozma çabası emelinde olduklarına işaret etmiştir. Baha Saîd'e göre Türkiye düşmanları millî birliği bozmak için mezhep ayrılıkları çıkarmaya çalışmışlardır. Ayrıca doğunun bir çok illerinde yaşayan bozulmamış Türk soyuna mezhep sözü verilerek Türk birliği bozulmak istenmiştir. Bahâ Saîd, makalesinde doğuda Ermeni nüfusunu çoğunluk olarak göstermek için doğu illerinde her âyin mensubunu bir milliyet şeklinde gösterilmek istenmesinin yanlışlığına dikkat çekmiştir. Çünkü ona göre, "Nastûrîlik, Kızılbaşlık, Sûfiyân, Sürek, Yezîdî, Tâvûsî vb. mezhepleri ayrı bir milliyet olarak kabul etmek yanlıștır. Bu mezhepler ancak dinî bir inanış olarak kabul edilebilir". Yine ona göre "Türk toplulukları arasında Tâvûsîlik ve Yezîdîlik gibi inançlar bulunmamaktadır. Tâvûsîlik ve Yezîdîliğe inananlar yalnız İran ve Osmanlı topraklarında yaşayan ve Kürtçe konuşan çok az sayıdaki insanlar arasında rastlanmaktadır. Sûfiyân, Kızılbaş ve Tahtacılar ayrı ayrı inanç mensupları değildirler bunların hepsi "Şiî" ve "Hacı Bektaş Ocağı"na bel bağlamış Türklerdir." Ona göre Türkiye düşmanlarının bütün amaçları Türkler arasına ayrılık sokmak ve millî birliği bozmaktır. ${ }^{60}$

58 Bahâ Saîd, Türkiye'de Alevî̀-Bektaşî, Ahî ve Nusayrî Zümreleri, 91-93.

59 Bahâ Saîd, Türkiye'de Alevî-Bektaşî, Ahî ve Nusayrî Zümreleri, 94-98.

60 Bahâ Saîd, Türkiye'de Alevî-Bektaşî, Ahî ve Nusayrî Zümreleri, 99-100. 
Bahâ Saîd, Memleket gazetesinde yayınlanan dördüncü makalesinde Çepnilerin menşeini, yaşadıkları yerleri ve bazı âyinlerini olduğu gibi ele alırken ${ }^{61}$ beşinci makalesinde ise eski bir velâyetnameden alıntı yaparak Çepnîleri anlatmaya devam etmiş ve ayrıca Çepnîlerin ocakları, ocak ihtilafları, Erkân-1 Evliya ve Çevgân Meydanı gibi âyinlerinden de bahsetmektedir. Bahâ Saîd, Anadolu'daki Alevî topluluklarının samimiyetle Hacı Bektaş'a bağlı olmamalarından, Bektaşzâdeleri ve Şeyhülislâmlık makamını sorumlu tutmaktadır. O, Alevîleri Tahtacı ve Sûfiyân olmak üzere ikiye ayırmıştır. Tahtacılar dişında Anadolu'daki Türk Alevî zümrelerinin kendilerini Sûfiyân olarak isimlendirdiklerini ve Sûfiyânların da iki kısma ayrıldıklarını anlatır. Ona göre Bektaşîler arasındaki ayrılık sebepleri, inanç ve iman ihtilaflarından ziyade menfaât meselesinden kaynaklanmıştır. Yine ona göre Anadolu'daki Kızılbaşların Yezidîlikle bir bağları söz konusu değildir. Çünkü Yezidî veya Tâvûsî mezhebine bağlı Türk boyunun bulunması mümkün görünmemektedir. 62

Bahâ Saîd, Memleket gazetesindeki son makalesinde ise Anadolu'daki, Alevî ve Bektaşîlerin itikatlarına Taoizm ve Natürizm gibi tabiattan mülhem kült ve ilkelliklerinin tesiri bulunduğunu belirtmekte, kanıt olarak da Süreklerin kabul etiği "atam gök, anam yer" ilkesini göstermektedir. Bahâ Saîd'e göre Bektaşîliğin Balım Sultan'dan sonra "On İki” erkanı, eski Bektaşiliğin Sekiz'li erkanının havârileşmiş biçimi gibi "üç boğmak" da teslis inancından ilham almiştır. ${ }^{63}$

Bahâ Saîd’in Alevî zümreleri ile ilgili seri araştırma yazıları sonraki yıllarda Türk Yurdu dergisinde yayınlanmaya devam etmiştir. "Türkiye'de Alevî Zümreleri: Tekke Alevîliği-İçtimaî Alevîlik" başlıklı makale bunlardan birtanesidir. Müellif, makalesinin başında Türkiye'deki mezheplerle ilgili zümrelerin oluşumunu incelemenin, özellikle Alevî ve Bektaşîlerin kimlik meselesinin aydınlatılmasının Türk toplumu için millî bir görev olduğunu kaydeder. Cumhuriyet Türkiye'si sınırları içinde yaşayan Alevî-Bektaşî gibi toplulukları, Huristiyan zümrelerinin kendi mühtedileri diye kaydettiklerine dikkat çekerek şu ifadelere yer verir: "Çepni, Avşar, Kargın, Tahtacı Alevîleri nüfus yönüyle kalabalık bir topluluk oluşturmalarına rağmen, çoğunlukla "Ortodoks" Rumların, Türkleștirilmiş zümreleri diye kabul edilirdi. Kiğı, Dersim, Tercan, Iğdır, Bayburt vb. Alevîleri de Ermenî nüfus kayıtlarında birer ilâve olarak yer alırdı." Makalesinin devamında o, bu çalışmalar için çaba göstermesini Anadolu'da

61 Bahâ Saîd, Türkiye'de Alevî-Bektaşî, Ahî ve Nusayrî Zümreleri, 101-102.

62 Bahâ Saîd, Türkiye'de Alevî-Bektaşî, Ahî ve Nusayrî Zümreleri, 103-106.

63 Bahâ Saîd, Türkiye'de Alevî-Bektaşî, Ahî ve Nusayrî Zümreleri, 107-110. 
yaşayan Alevî camiasının "Hıristiyan dönmesi" unsurlar olarak gösrerilmesinin sebep olduğunu anlatır. Baha Saîd'in Alevî-Bektaşi toplulukları ile ilgili yazdıklarına "Yıkılan Türk Ocağı'nın dinsiz çocukları şimdi de Kızılbaşlık propagandası yapıyor" şeklinde cevap verilmiştir. Ona, lanetler, küfürler yağdırılmış, hatta kafir olmakla suçlanmış ve yazılarına sansür konulmuştur. ${ }^{64}$

Yeni Türkiye'nin temelleri atılırken "kendimizi bilmek için çalışabiliriz" diyen Bahâ Saîd, Cumhuriyet Türkiyesi'nin Türk birliği ile yaşayacağını vurgulamıştır. Alevî-Sünnî kavgasının geride kaldığının altını çizmiştir. ${ }^{65}$

Bahâ Saîd, Anadolu'da yaşayan Türkmen ve Yörüklerin Alevî tekkelerine katılmalarının doğru ve aynı zamanda lüzumlu bir yaklaşım olduğunu şu cümlelerle ifade etmiştir: "Adetlerine, ulusallığına gönül veren Türkler, kozmopolitliğe alışamadı. Arapların beynel milel gürüşüyle Türklerin ulusal ülküsü birleşemedi; sonsuza dek de birleşemeyecektir. Bu nedenle en gelenekçi en halis Türkler, Yörükler, Türkmenler ve en sonra en aydın, en zeki, en heyecanlı Türkler, özgürlük hazzını hissedecek bir ocak araștırdıkları zaman onu Alevî Tekkeleri'nde buldular. Çünkü oralarda "milli kurtuluş" vard1." 66

Makalesinin devamında Bahâ Saîd, kızılbaşlık akîdesinin tariksel menșeleri ile bunların teșekkülünde Yunus Emre, Âșık Paşa ve Hacı Bektaş Veli gibi kişilerin önemine dikkat çekmiştir. Ayrıca Kızılbaşlara "dostlarım" diye hitap ederek onların iyi ve kötü yönlerini açıkça ortaya koymaktadır. O, Hacı Bektaş âyini'nin bütünüyle Türkçe olduğunu ispat etmeye çalışmıştır. Ona göre, Cumhuriyet Türkiyesi'nde kazananlar Kızılbaş Alevîleri ve nispeten de Bektaşîlerdir. Türk-Alevî müessislerinin amacı, Türklerin lisanını ve nesebini korumaktır. Ayrıca o, Kızılbaş kadınına atılan iftiraları da eleştirmiştir. ${ }^{67}$

Aynı zamanda Bahâ Saîd, makalesinde Osmanlı Devleti ile AlevîBektaşîlik ve Türklük arasındaki münasebetlere de yer vermiştir. Türklere ve Türklüğün önemli temsilcilerinden Alevî ve Bektaşîleri haksız yere baskı altına alan Osmanlı Devletinin uyguladığı bu tür politikalara eleştirilerini şu şekilde dile getirmiştir: "Türklüğünü, dilini, milliyetini, İslâm öncesi töresini din şeklinde koruyan Alevîler,

64 Baha Saîd, “Türkiye'de Alevî Zümreleri: Tekke Alevîliği-İçtimaî Alevîlik”, Türk Yurdu, 4/21 (Eylül 1926), 193-194.

65 Baha Saîd, "Türkiye'de Alevî Zümreleri: Tekke Alevîliği-İçtimaî Alevîlik”, 194195.

66 Baha Saîd, "Türkiye'de Alevî Zümreleri: Tekke Alevîliği-İçtimaî Alevîlik”, 205.

67 Baha Saîd, "Türkiye'de Alevî Zümreleri: Tekke Alevîliği-İçtimaî Alevîlik”, 195208 
Osmanlı döneminde bazen Celâlî, bazen Cemâlî, bazen Zındık ve bazen de dinsiz oldu. Devlet adamları; Hırvat, Latin, Grek, Ermeni, Gürcü, Germen, Çerkes, Arnavut vb. yetmiş iki buçuk milletten türemişti. Onlar Türk'ün omuzunda, Türk'ün kilıcında ekmek bulmuşlar ve yine onu tahkire özenmişlerdi. Osmanlı Padişahları bu binbir çeşit süt ve kandan türemişlerdi. Türklüğü değil taç ve taht1 seviyorlardı. Atalarının kendilerine sağladığı ellerin sınırlarını çizen Türk kemiklerini unutmuşlard1."68

Makalesinin sonunda Kızılbaş ve Bektaşîlerin şecerelerini incelediğini belirten Bahâ Saîd, Şamanizm ve Kızılbaş zümreleri arasında bir bağ kurarak Anadolu Alevîlerini yalnızca Hz. Ali ve On İki imam inancı ile irtibatlandırmanın yanlış olduğunu, aksine bu camianın ritüel ve erkanının Oğuz töresinin ve Şaman Türk çadırının aynıs1 olduğunu şu şekilde kaydeder: "Anadolu Türk Alevîlerinin şecerelerini incelerken bunları Ali'ye ve İmamiyyeye bağlamak kesin olarak doğru olmaz... Bu topluluğun âyin ve tarikat erkânı, Oğuz töresinin, Şaman Türk Çadırının aynısıdır, farklı değildir." Bununla beraber Bahâ Saîd, Anadolu'daki Alevî zümrelerini tahkik ederken, onların herhangi bir ideoloji ve mezheple bağlantısını ortaya çıarmaktansa, onları olduğu gibi kabul etmenin hakikate uygun ve daha başarılı bir araştırma yöntemi olacağını vurgular. O, Alevîleri bazan Mazdekî ve İştirâkî fikirler ile kaydetmek isteyenlerin bulunduğunu ancak Kızılbaşlık ve Bektaşîliğin, Mazdekî ve İştirakî olmadığını, onların sadece millî benlik üzerine inşa edilmiş ve gerçekten de başarılı bir müessese olduğunu belirtir. 69 Ona göre Alevîlik veya Kızılbaşlık doğrudan doğruya kaynağını Şamanizm ve Oğuz töresinden almıştır. ${ }^{70}$

Bahâ Saîd, "Sûfiyân Süreği: Kızllbaş Meydanı" başlıklı makalesine "Sûfiyân" ve "Sufi" terimlerini açıklayarak başlamıştır. Bu terimlerden kastedilenin Anadolu Alevîleri arasında Kızılbaş denilen cemiyetin bulunduğunu ve Şah İsmail Safevî'ye nispetle "Safeviyye" ifadesini kullanmamak için kabul edildiğini belirtmektedir. Ayrıca Sûfiyân toplulukların On İki İmamcı olduğunu Balım Sultan'ın, Bektaşîlere açtığı On İki İmam Meydanı'nda On İki İmamcı kadar Sûfiyân'da da olduğunu kaydeder. Örnek olarak Kırşehir Hacı Bektaş

68 Baha Saîd, “Türkiye'de Alevî Zümreleri: Tekke Alevîliği-İçtimaî Alevîlik”, 209.

69 Baha Saîd, “Türkiye'de Alevî Zümreleri: Tekke Alevîliği-İçtimaî Alevîlik”, 209210.

70 Bahâ Saîd'in Alevîlikle ilgili görüşleri hakkında bkz. Aydın Aras, Oryantalistlerin Alevîlik-Bektaşîlik Araştırmalarının Eleştirisi, (Ankara: Hacı Bayram Veli Üniversitesi, Lisans Üstü Eğitim Enstitüsü, Yüksek Lisans Tezi, 2019), 37-40. 
Ocağ1 ile Sûfiyân teşkilatı meydanlarının hemen hemen aynı olduğunu şekillerle göstererek vermektedir. ${ }^{71}$

Bahâ Saîd, Anadolu Kızılbaşların asliyetlerini korumaları nedeniyle, onların Türk Beyliği açısından dikkatli bir şekilde incelemeyi kendisini zorunlu hissettiğini söyleyerek amacını ve metodunu ortaya koymuștur. Ona göre Anadolu Alevîleri Sûfiyân olsalar da Safevî değildirler. Şah İsmail'in kurduğu veya onun atalarından miras kalan bir sürek ve âyin de bulunmamaktadır. Safevî devleti, kendi dönemlerinde olduğu gibi günümüzde, İran'da süregelen Caferîlik, gaip imamin yerine mevcut müctehitleri kabul etmiştir. Yine Ona göre müctehidi taklit etmek bakımından İran Alevîliği ile Şiîlik arasında çok az fark bulunmaktadır. Sünnîler dört müctehidi taklit ederken resmî İran Alevîliği yaşayan müctehitleri taklit etmektedirler. Ona göre Bektaşî ve Sûfiyânlar, Caferî mezhebini resmen kabul etmek zorunda kalsalar da ne Bektaşîlerde ve ne de Sûfiyânlarda bu mezhebin geçerliliği söz konusu değildir. Dolayısıyla ona göre Anadolu'daki Sûfiyân Süreği'ni Oğuz ve Şaman töreciliğiyle anlatmaktan başka bir çare bulunmamaktadır. ${ }^{72}$ Ancak son dönem araştırmacılardan Ocak'a göre, Şamanizm, Türlerin asıl dini değildir. İlk dönemlerde Türkler arasında varlığı ispatlanamamış olup sonradan girmiştir ${ }^{73}$ Ocak'a göre Alevîlik ve Bektaşîlik inançlarının temelinde eski Orta Asya Şamanizminden fazla özellikle Budizm, Zerdüştlük, Maniheizm, Mazdekizm, antik İran dinleri, Hıristiyanlık ve Yahudiliğin etkisi söz konusudur. ${ }^{74}$

Bahâ Saîd, Kızılbaşların makam sahibinin "Çelebi" olduğuna inandıklarının kaydeder. Ancak Çelebilerin kendilerini Hacı Bektaşı Veli'nin torunları oldukları iddialarına karşı çıkar. Çünkü ona göre Hac1 Bektaş'in çocuğu olmadan vefat ettiği tarihi bir gerçektir. Ocakların, birbirlerine göre üstünlükleri olduğunu belirten Bahâ Saîd, Dersim Ocağı'nın Yezîdî âyinine bağlı olmasından dolayı diğerlerine göre daha Rafızî olarak kabul görüldüğünü ifade eder. Ancak Bahâ Saîd, Anadolu Kızılbaşlarının, Yezîdîleri, Nusayrîleri ve Dürzîleri yadırgamadıklarını, Ehl-i Sünnet'ten sonra en az sevdiklerinin Bektaşîler olduğunu keydeder. ${ }^{75}$

Makalenin devamında Bektaşîlerde ve Sûfiyânlarda meydanların önemini vurgulayan Bahâ Saîd, Sûfiyân Meydanlarından; "Mihman

\footnotetext{
71 Bkz. Bahâ Saîd, "Sûfiyân Süreği: Kızılbaş Meydanı”, Türk Yurdu, 4/22 (Teşrini Evvel 1926), 325-327.

72 Bahâ Saîd, "Sûfiyân Süreği: Kızılbaş Meydanı", 328-330.

73 Ahmet Yaşar Ocak, Alevî ve Bektaşî İnançlarının İslâm Öncesi Temelleri, (İstanbul: İletişim Yayınları, 2000), 71-73.

74 Ocak, Alevî ve Bektaşî İnançlarının İslâm Öncesi Temelleri, 16.

75 Bahâ Saîd, "Sûfiyân Süreği: Kızılbaş Meydanı", 330-332.
} 
Meydanı", "Muhabbet Meydanı", "Kerbelâ Meydanı", "Eş Meydanı" ve "Düşkünlük Meydanları"nın özelliklerini kısaca açıklamıştır. Bu meydanları birbirinin aynısı olarak gören Bahâ Saîd, esas meydanın "Kızılbaş Sûfíliğine Kabul Töreni" anlamına gelen, Bektaşî ve Alevîlerin ise "Nasip Meydanı" diye isimlendirdiği "Eş Meydanı" hakkında geniş malumatlar vermeyi daha uygun görmüştür. ${ }^{76}$

Bahâ Saîd, Türk Yurdu'nda "Sûfiyân Süreği: Kızılbaş Meydanı, Düşkünlük” adlı makalesiyle Kızılbaş meydanlarını anlatmaya devam etmiştir. O, makalesinde "Düşkünlük Meydanı"nı asıl meydanlardan biri olarak gördügü için bu meydanı ayrıntılı bir şekilde titizlikle tasvir etmiştir. Ona göre "Düşkünlük Meydanı", "Kızılbaş erkanında hukuki kudret ve cezanın icra kuvveti" niteliğindedir ve ceza çeşitleri işkencenin tuhaf bir sahnesidir. Makalenin başında Anadolu Alevîlerinde hukukun ne anlama geldiğini şu şekilde özetlemiştir: Zina ve hırsızlık yapmak, adam öldürmek, dede ve meydan erenlerine yalan söylemek, birden fazla kadınla evlenmek, nikahlı kadını boş yere boşamak, Sünnî birisiyle evlenmek, Pîr ve Ocak hakkını vermemek, Alevî sırrını ifşa etmek ve gerektiğinde sufî dostlardan muaveneti esirgemek yasaktır. ${ }^{77}$ Söz konusu maddeler genel yasaklardan olup bunlara aykırı davrananlar sorumludur. Toplumda genel düzenin devamlılığını sağlamak için cezaya çarptırılır. Makalenin devaminda Bahâ Saîd, Anadolu Alevîlerinde hukukun maddelerini ve takdir edilen cezaları ayrı ayrı anlatmıştır. ${ }^{78}$

Bahâ Saîd, "Kızılbaş Meydanı"na kar1-kocanın başka çiftlerle birlikte girmesini "mum söndü" şeklinde iftiraya dönüştüğünü şu şekilde anlatmaktadır: " Meydan erkanının bu kuvvetli güvenlik ve kuruluşuna göre, bazı şahısların gerek Kızılbaş ve gerekse Bektaşîlik hakkındaki namusa aykırı davrandıklarına dair suçlamalar, ancak kara çalma cinsinden bir iftira olmalıdır. Bu kurumun güvenliğinin dışında meydana gelebilecek ahlakî saldırılar varsa bile, bu kişisel ve kendince yakışıksız davranışın kuruma izafe edilmesine hiç gerek yoktur."79

Bahâ Saîd, Alevîlerin, Caferîlerin ve Şiîlerin tehlikenin muhtemel olduğu yerde takiyyeyi bir inanç haline getirmelerini ve bunu çocukluktan itibaren yalan ve riaya sevkettiği gerekçesiyle eleștirmektedir. Çünkü o, "yalan oyunlar" ile ilkel bir eğitim vermenin o tuplumu çürütmekten başka bir işe yaramayacağı görüşündedir.

76 Bu meydan hakkında geniş malumat için bkz. Bahâ Saîd, "Sûfiyân Süreği: Kızılbaş Meydanı”, 332-360.

77 Bahâ Saîd, "Sûfiyân Süreği: Kızılbaş Meydanı, Düşkünlük", Türk Yurdu, 4/23 (Teşrin-i Sani 1926), 404.

78 Bkz. Bahâ Saîd, "Sûfiyân Süreği: Kızılbaş Meydanı, Düşkünlük", 406-413.

79 Bahâ Saîd, "Sûfiyân Süreği: Kızılbaş Meydanı, Düşkünlük”, 406. 
Ona göre Şîa'daki "takiyye"ye karş1lık olarak Kızlbaşl1lıkta "sır" vardır. Ancak Türkiye'deki Bektaşî ve Kızılbaşların "sır" anlayışı Şia'daki takiyye anlayışından farklıdır. Çünkü Türkiye'deki Kızılbaș Alevîleri son derece özgür oldukları için kendilerini gizlemeye gerek görmemişlerdir. Dolayısyla da yalancı olmaktan korunmuşlar ve dürüst hareket etmişlerdir. ${ }^{80}$

Bahâ Saîd, bir çeşit "aforoz" olarak isimlendirdiği "Düşkünlük Meydanı"nı yani Düşkünler için yapılan tören ve açılan meydan hakkında bizleri ayrıntılı olarak bilgilendirmektedir. ${ }^{81}$ Ayrıca makalesinin son kısmında "Düşkünlük Meydanı"nda belirtilen cezaları ile Düşkünlük ceza ve tazminatlarını maddeler şeklinde sıralamıştır. ${ }^{82}$

Bahâ Saîd, Anadolu Kızılbaşları hakkında yaptığı alan araştırması ile Anadolu Kızılbaşları denilen topluluğun, genel olarak inanç şekillerinde, Budizm, Maniheizm, Şamanizm, Mazdekîzm, İslâm ve Hıristiyanlık gibi dinlerden ne kadar etkilendikleri hususunun ayrıca araştırılması gerektiği sonucuna ulaşmıştır. ${ }^{83}$

"Anadolu'da Alevî Zümreleri: Tahtact, Çepni, Hardal Türkmenleri Yahut Yan Batır Süreği” adlı makalesinde Bahâ Saîd, Tahtacılar hakkında detaylı bilgiler vererek diğer Alevî kollarının Tahtacı kolundan ayrılma olduklarını, onlara benzeyen ortak yönlerini ve esas geleneklerini ortaya koymaya çalışır. "Hey kurbanın olam Zülfikar Ali" ile başlayan bir nefesin felsefî tahlilini yaparak "Sarı Kız Efsanesi"ni anlatır. ${ }^{84}$ Tahtacı Türkmenlerinin, Çepni Türklerinden farklı zihniyetteki bir Alevîliğe inandıklarını tespit eder. ${ }^{85} \mathrm{O}$, Tahtacıların kendilerini Hacı Bektaş Ocağı'nın öz evladı görerek, öteki Alevîleri dışladıklarını ve Kızılbaşlar gibi Bektaşî dervişlerinden de hoşlanmadıklarını belirtir. Ayrıca Bahâ Saîd, Tahtacıların, Şamanlarıla şöhret bulan Türk zümrelerinden bir ocağa bağlı bir inanc1 devam ettirdiklerini bir ihtimal olarak görür. ${ }^{86}$ Bahâ Said'in bu arasstırmalarından Tahtacıları ve Tahtacıların yaşattığı AlevîBektaşiliği detaylı bir şekilde incelediği anlaşılmaktadır.

80 Bahâ Saîd, "Sûfiyân Süreği: Kızılbaș Meydanı, Düşkünlük”, 410-411.

81 Bahâ Saîd, "Sûfiyân Süreği: Kızılbaş Meydan1, Düşkünlük”, 413-420.

82 Bahâ Saîd, "Sûfiyân Süreği: Kızılbaş Meydan1, Düşkünlük", 420-421.

83 Bahâ Saîd, "Sûfiyân Süreği: Kızılbaş Meydan1, Düşkünlük", 421.

84 Bahâ Saîd, "Anadolu'da Alevî Zümreleri: Tahtacı, Çepni, Hardal Türkmenleri Yahut Yan Batır Süreği”, Türk Yurdu, 4/24 (Kanun-i Evvel 1926), 484-486.

85 Bahâ Saîd, "Anadolu'da Alevî Zümreleri: Tahtac1, Çepni, Hardal Türkmenleri Yahut Yan Batır Süreği”, 488.

86 Bahâ Saîd, "Anadolu'da Alevî Zümreleri: Tahtac1, Çepni, Hardal Türkmenleri Yahut Yan Batır Süreği”, 492. 
Bahâ Saîd'in Bektaşîlerle ilgili yine Türk Yurdu'nda seri bir şekilde yayınlanmıs hacimli makaleleri bulunmaktadır. "Bektaşiler-I" adlı makalesinde Batınîler, Batınîlerin çöküşü, Batınî İsmailiyye mezhebi, Bektaşîler ve Hacı Bektaş Veli, yakın çevresi ve çağdaşları ile ilgili konuları araştırmıştır. Batınîler hakkında özet bilgiler veren Bahâ Saîd, onları İslâm dünyasının gerek dinî ve gerekse siyasî tarihinde güçlü etkileri bulunan bir zümre olarak tanımlar. Ayrıca doğu tarihi ile ilgili güvenilir belgelere sahip olunmamasına rağmen Batınî toplulukların benimsediği fikrî, dinî ve ictimaî kanaatleri ile ilgili ciddi incelemeler neticesinde fikir vermeye çalıştığını belirtir. ${ }^{87}$ Batınî İsmailiyye mezhebininin tarihçesini 88 inceleyen Bahâ Saîd, Batınîlerin dağılışından sonra Türkiye'de Bektaşîlik, Mevlevîlik gibi tarikatlar aracılığıyla günümüze kadar varlıklarını devam ettirdiğini kaydeder. ${ }^{89}$ Bahâ Saîd, makalesinin sonlarında Hacı Bektaş Veli ve muasırdaşları ile ilgili bazı önemli malumatlar paylaşır. ${ }^{90}$

Bahâ Saîd, Türk Yurdu'nda yayınlanan "Bektaşîler-II" adlı makalesinde Ahîler Mevlevîler, Hacı Bektaş Veli ve muasırları hakkında önemli bilgiler verir. Makalesine Ahîler hakkında bazı bilgileri paylaşarak başlar. O, Ahîliğe bir tarikat ve mezhep gözüyle bakılmaması gerektiğini, onların zühdî âyinlerinin olmadığını ve Bektaşîliğin teşekkül ve kuruluşunda hazırlanmış birer ocak mahiyetinde bulunduklarını belirtir. ${ }^{91}$

Babaîleri anlatırken babalık ünvanının Bektaşî mürşidlerine nası1 intikal ettiği ve bu kelimenin özellikleri ile alameti hakkında araştırmalar yapmıştır. "Baba" kelimesinin Türkçemizde "ata" yerine kullanıldığını belirten Bahâ Saîd, Bektaşî şeyhleri için kullanılan "baba" kelimesi ile Orta Asya kökenli Türkmenler tarafından kullanilan "ata" kelimesine benzer olduğuna dikkat çekmiştir. Ahîlerle Babaîlerin, Anadolu'da Bektaşiliğin tam bir şekilde içine girmiş iki kurum olduğunu, Hacı Bektaş'in hem Ahîler'den kuşak bağladığını, onlarla sıkı ve sürekli münasebetleri bulunduğunu, hem de Babaîlerle birlikteliğini ele alır. Fakat Babaîlerin Batınî İsmailîler gibi ihtilalci olduklarını ve dini yenileyici bir rol üstlendiklerini kaydeder. ${ }^{92}$ Şeriat, tarîkat, hakîkat ve marifet gibi dört kapıdan Bektaşiliğin anladığı mana ve gayeleri inceler. Anadolu Kızılbaşlarının bu dört kapının açıldığı hayat sarayının samimi birer

\footnotetext{
87 Batınîler hakkında geniş bilgiler için bkz: Bahâ Saîd, "Bektaşiler-I", Türk Yurdu, 5/26 (Subat 1927), 128-135.

88 Bkz. Bahâ Saîd, "Bektaşiler-I", 135.

89 Bahâ Saîd, "Bektaşiler-I", 141.

90 Bkz. Bahâ Saîd, "Bektaşiler-I", 141-150.

91 Bahâ Saîd, "Bektaşiler-II", Türk Yurdu, 5/27 (Mart 1927), 196-197.

92 Bahâ Saîd, "Bektaşiler-II", 197-205.
} 
örnek teşkil ettiğini açıklar. Son olarak da Bahâ Saîd, Bektaşîliğin, ilk teşekkül ettiği dönemlerde Türklerin dini, dili ve ve töresi; Ahîlik ve Babaîlik derlenmiş İslâmî tasavvuf biçimleri, Hint ve İran'a özgü manevî fikirlerin Türk kamoyuna empoze edilmesinden etkilendiğini; bu düşüncelerde en belirgin, güçlü ve tesirli ilkenin Türk töresi olduğunu anlatır. ${ }^{93}$

Bektaşîlerle ilgili son makalesinde Bahâ Saîd, Bektaşîliğin Balım Sultan öncesi dönemin önemli şahsiyetlerinden Şeyh Safuyiddin, Şeyh Cüneyd, Şah İsmail ve Yavuz Sultan ile ilgili bilgi ve belgelere dayanarak değerlendirmelerde bulunur. Daha sonra Bektaşîliğin ikinci dönemine ilişkin "Balım Sultan Erkânı" ve zamanımıza kadar ulaşan Bektaşî öğretisini inceler. "Balım Sultan Erkânı"nı anlatırken onun aracılığıyla Bektaşîliğe Şarabın, Mücerredliğin, İbahîliğin, Hurûfîliğin ve Teslisin girişini ve uygulamadaki metotlarını ayrı ayrı açıklar. Bektaşîliğin çevreye göre şarabı mübah kılmasından ve cem meydanına kadınları almasından basska sır diyecek bir fiillerinin olmadığını ifade eder. ${ }^{94}$ Budizm ve Hıristiyanlıkta olan Mücerredliği İslâm'ın ve Bektaşilliğin kabul etmediğini Balım Sultan'la birlikte Bektaşîliğe girdiğini dolayısıyla da Anadolu Alevîlerinin bütünüyle Bektaşî tekkesinden ayrıldıklarını anlatır. ${ }^{95}$ Balım Sultan erkânında görülen Hurûfílik kurumunun Hacı Bektaş zamanından daha sonraları ortaya çıktığını anlatır. ${ }^{96}$ Onun tespitlerine göre Hac1 Bektaş Ocağı ve yeni 1slahatçısı Balım Sultan; Bedreddin Simavi'nin sosyalizminden, Hurûfîlik anarşizminden ve bu fikirleri iktidara taşıyan Şah İsmail'in ortaya çıkmasından etkilenmiştir. ${ }^{97}$

Bahâ Saîd'in Türk Yurdu dergisinde yayınlanan Alevîlik ve Bektaşîlik ile ilgili saha araştırmalarının, daha sonra yapılacak olan çalışmalara rehberlik edecek ve dayanak oluşturacak ilmî esaslara dayalı son derece önemli çalışmalar olduğunu söylemek mümkündür.

\section{2. Anadolu'daki Nusayrî Zümreleri Hakkındaki Araștırması}

Bahâ Saîd'in Adana Türk Ocağı'na ithafen yazdığı ve Türk Yurdu'nda "Anadolu'da Gizli Mabetlerden: Nusayrîler ve Esrar-ı Mezhebiyeleri" adıyla yayınlanan Nusayrîlerle ilgili bir araştırma makalesi bulunmaktadır. Bu çalışma, İskenderun körfezinden Akdeniz'in en ücra dağlarında ve sahillerdeki şehirlerde, ayrıca Mersin, Adana, Tarsus ve Silifke yörelerinde yoğun bir şekilde

93 Bahâ Saîd, "Bektaşiler-II", 209-216.

94 Bahâ Saîd, "Bektaşiler-III”, Türk Yurdu, 5/28 (Nisan 192,) 330.

95 Bahâ Saîd, "Bektaşiler-III", 330.

96 Bahâ Saîd, "Bektaşiler-III", 333.

97 Bahâ Saîd, "Bektaşiler-III", 336. 
yaşayan Nusayrîlerin inanç yapısıyla ilgili bilimsel bir araştırma makalesidir. Araştırmada Nusayrîlerin, temel kuramlarındaki birtakım ufak nüanslar ve ictihatlar nedeniyle Haydarî, Mütevâlî, Gryâbî ve Kamerî sseklinde dört gruba ayrılan mezheplerin teşekkülleri, usulleri, fikrî kaideleri, iman telkinleri ve şartları, sır ve motifleri oldukça kapsamlı bir şekilde incelenmiştir.

Makalenin hemen başında Nusayrîlerin, Arap, Türk veya başka bir ırka mensubiyetlerinin kesin olarak belli olmadığ belirtilmektedir. Özellikle Adana Nusayrîlerinin tamamen ayrı bir tip ve karakterlerinin olduğuna dikkat çekilmektedir. Bahâ Saîd, Nusayrîlerin, nesep ve kültürlerinin unsur ve kaynaklarıyla ilgili detayl1, bilimsel tetkiklerde bulunmayı, onların ulusal tabiatlarını belirlemeyi önemli bir mesele olarak görmektedir.

Bahâ Saîd, yaptığı araştırmalardan yola çıkarak Nusayrîlerin mezheplerine ilişkin metotları ve fikrî kaidelerinin sayı, harf ve yıldızlar gibi metafiziksel bilimlere istinat etmesi, hassaten de inançlarının "Buda-Dalay Lama" itikatlarına benzemesini dikkate alarak onların bu özellikleriyle Moğol ve Tibet dinlerinin sâlikleri olduğunu belirtir. Dolayısıyla Bahâ Saîd, bu benzerliklerden yola çıkarak Nusayrîlerin inançlarının kendilerinden önce oralarda yaşayan "Sâmî" inancına mensup olamayacaklarını ileri sürer. ${ }^{98}$

Nusayrîlerin nüfus kayıtlarında Müslüman olarak gösterildiklerine ve dolayısıyla da onların nüfusları hakkında kesin ve istatistikî bilgi edinmenin zorluğuna dikkat çekmektedir. Ancak Adana Türk Ocağı'nın desteğiyle yaşadıkları bölgelerdeki Nusayrî adlarını ve nüfuslarını ilgililere gönderilen bir yazıyla doğru bir şekilde tespit edebileceğini belirtmektedir. Onun tahminlerine göre o zamanlar Anadolu'da yetmiş ile seksen bin civarında Nusayrî yaşamaktadır. ${ }^{99}$

Bahâ Saîd, Nusayrîlerin iman telkininin şartlarını anlatırken onların inançlarını Alevî-Bektaşî inançlarıyla karşılaştırmaya çalışır. Mesela ona göre Nusayrîlerin iman telkini ile Kızılbaşların Sûfiyânî âyine kabulleri, Nusayrîlerdeki "deli-i beyt"in, Bektaşî ve Kızılbaşlardaki "talib-i tathiren"e, Talib'in Şeyhu'l-Velâye önünde diz çöküşünü Bektaşîlerde "tığ bend" ve Sûfîyânda ise "lâ bend"e, Nusayrîlerdeki "zülfekâr"1 Tahtacilarda "alaca değnek" ile Sûfiyân

\footnotetext{
98 Bahâ Saîd, “Anadolu'da Gizli Mabetlerden: Nusayrîler ve Esrar-1 Mezhebiyeleri”, Türk Yurdu, 5/25 (Kanun-I Sani 1927), 7-8.

99 Bahâ Saîd, “Anadolu'da Gizli Mabetlerden: Nusayrîler ve Esrar-1 Mezhebiyeleri”, 9.
} 
Süreklerindeki "çevgân çomağı", "pence ve melheme ağacı" birbirine benzemektedir. 100

Nusayrîlerle ilgili daha ayrıntılı çalışmaların gerektiğini belirten Bahâ Saîd, makalesinin sonunda "Türk camiası içinde vatandaş olan bu zümrenin hislerini ve psikolojilerini bilmek, bizim için ne kadar faydalı ise onlar için de o kadar yararlıdır" ifadesine yer vermektedir. 101

\section{Sonuç}

Bahâ Saîd, Osmanlı'nın son Cumhuriyet'in ilk yıllarında yaşayan, Anadolu'daki Alevîlik-Bektaşîlik ve Nusayrîlik üzerine yaptığı alan araştırmaları ile dikkat çeken önemli bir şahsiyettir. O, gerek kendi isteğiyle gerekse de İttihat ve Terakki'nin kurucularından Sadrazam Talat Paşa hükümetinin görevlendirmesiyle olsun Anadolu'daki Alevî-Bektaşî ve diğer zümreleri yerinde tetkîk ederek ayrıntılı bir araştırma ve inceleme yapmıştır. Bahâ Saîd'in, uzun bir çalışmanın mahsulü olan Alevîlik-Bektaşîlik ve Nusayrîlik ile ilgili araştırmaları bașta Türk Yurdu mecmuası olmak üzere Muhibbân, Memleket ve Meslek gibi gazete ve dergilerde neşredilmiștir. Türk Yurdu'nda yayınlanan makaleleri, Türkiye'de Alevî zümreleri arasında ilmî metotlarla yapılmış ve detaylı bilgiler veren saha araştırmalarını oluşturmaktadır.

Bahâ Saîd'in, Alevîlik-Bektaşîlik ve Nusayrîlikle ilgili çalışmaları; "Anadolu'da Gizli Mabetlerden: Nusayrîler ve Esrar-ı Mezhebiyeleri", "Sözün Doğrusu”, "Türkiye'de Alevî Zümreleri: Tekke Alevîliği-İçtimaî Alevîlik", "Sûfiyân Süreği: Kızılbaş Meydanı I-II", "Anadolu’da Alevî Zümreleri: Tahtact, Çepni, Hardal Türkmenleri Yahut Yan Batır Zümresi”, "Anadolu'da Gizli Mabetlerden Bektaşîler I-III", başlığ1 altında seri olarak Türk Yurdu dergisinde yayınlanmıştır.

Bahâ Saîd’in, Anadolu'daki Alevî-Bektaşî ve Nusayrî toplulukları ile ilgili yaptığı araştırma ve tetkiklerin değeri ve niteliği açısından önemli bir yeri vardır. Bu konuda önemli tespitler ortaya koymaktadır. Bahâ Saîd, Avrupalı ilim adamlarının Anadolu'daki Alevî-Bektaşi inancı ve diğer inanç mensupları hakkındaki görüşlerin tamamının yanlış olduğuna cevap vermek için Alevî ve Bektaşîler’in yaşadıkları bölgelerde Sosyolojinin araştırma tekniklerinden biri olan saha çalışması yani katılımcı gözlem ve görüşme denilen yöntemlerle araştırmalar yapmıştır. Dolayısıyla Bahâ Saîd, Alevî-Bektaşî ve diğer zümrelerle ilgili çalışmalarında saha araştırması ve doğrudan

\footnotetext{
100 Bu örnekler için bkz. Bahâ Saîd, "Anadolu'da Gizli Mabetlerden: Nusayrîler ve Esrar-1 Mezhebiyeleri”, 10-12.

101 Bahâ Saîd, "Anadolu'da Gizli Mabetlerden: Nusayrîler ve Esrar-1 Mezhebiyeleri", 27.
} 
mülakat metodunu kullanan ilk araştırmacılardan biri konumundadır. Onun araştırmaları Alevî-Bektaşî inancının kökenleri ve ritüelleri hakkında genel olarak bilgi vermektedir. Bahâ Saîd'in Alevî-Bektaşî zümrelerinin öğreti ve kültür yöntemlerini incelediği ve onlarda kadim Türklerin kültür izlerinin varlığını tespit ettiği görülmüsstür. Ancak İttihat ve Terakki hükümeti tarafindan görevlendirilmesi nedeniyle siyasî kimlikle araștırmalarını yapan Bahâ Saîd'in bazı değerlendirmelerinde ilmî isteklerden daha çok siyasî kaygıların ön plana çıktığı söylenebilir.

Diğer taraftan Bahâ Saîd'in Alevîlik ve Bektaşîlik üzerine yaptığ1 saha arasstırmalarında elde ettiği bulgular oldukça önem arz etmektedir. Çünkü o dönem kapalı bir kutu konumunda olan Anadolu'nun iç yüzü onun araştırma ve incelemeleriyle aydınlanmıştır. Ayrıca onun, Alevî-Bektaşî, Nusayrî, Ahî, Tahtacı ve Çepni zümreleri hakkında verdiği kıymetli malumatlar günümüz araştırmalarına rehberlik etmektedir.

\section{KAYNAKÇA}

Aras, Aydın. Oryantalistlerin Alevîlik-Bektaşîlik Araştırmalarının Eleştirisi. Yüksek Lisans Tezi, Hacı Bayram Veli Üniversitesi, Lisans Üstü Eğitim Enstitüsü, 2019.

Bahâ Saîd. Türkiye'de Alevî̀-Bektaşî, Ahî ve Nusayrî Zümreleri. (Girişi yazan ve yayına hazırlayan: İsmail Görkem), Ankara: Kültür Bakanlığı Yayınları 2000.

Bahâ Saîd. "Anadolu'da Alevî Zümreleri: Tahtac1, Çepni, Hardal Türkmenleri Yahut Yan Batır Süreği”. Türk Yurdu, 4/24 (Kanun-i Evvel 1926), 481-492.

Bahâ Saîd. "Anadolu'da Gizli Mabetlerden: Nusayrîler ve Esrar-1 Mezhebiyeleri”. Türk Yurdu, 5/25 (Kanun-i Sani 1927): 6-27.

Bahâ Saîd. "Anadolu'da İctimâî Zümreler ve Anadolu İctimâiyatı". Millî Talîm ve Terbiye Mecmuası, 5 (Ağustos 1334/1918): 18-32. 150.

Bahâ Saîd. "Bektaşiler-I". Türk Yurdu, 5/26 (Şubat 1927): 128-

Bahâ Saîd. "Bektaşiler-II". Türk Yurdu, 5/27 (Mart 1927): 196216.

Bahâ Saîd. "Bektaşiler-III". Türk Yurdu, 5/28 (Nisan 1927): 305341.

Bahâ Saîd. "Ehl-i Hak ve Atam Gök Anam, Yer". Muhibbân, $3 / 5$ (1 May1s 1335): 2-3. 
Bahâ Saîd. "Sûfiyân Süreği: Kızılbaş Meydanı Düşkünlük". Türk Yurdu, 4/23 (Teşrin-i Sanî 1926): 404-421.

Bahâ Saîd. "Sûfiyân Süreği: Kızılbaş Meydanı". Türk Yurdu, 4/22 (Teşrin-i Evvel 1926): 325-360.

Baha Saîd. "Tasavvuf ve Hür Mezhepler". Muhibbân, 3/4 (30 Kanunusani 1335): 1-2.

Bahâ Saîd. "Türkiye'de Alevî Zümreleri: Tekke Alevîliği-İçtimaî Alevîlik". Türk Yurdu, 4/21 (Eylül 1926): 193-210.

Birdoğan, Nejat. İttihat Terakki'nin Alevîlik-Bektaşîlik Araştırması (Bahâ Saîd Bey). İstanbul: Berfin Yayınları, 1999.

Erdoğan, Halide Özüdoğru. "Bahâ Saîd Bey". Ahi Ansiklopedisi, Ankara: Gümrük ve Ticaret Bakanlığı, 2016.

Görkem, İsmail. "Türk Folklor Araştırma Tarihinde Millî Talim ve Terbiye Cemiyeti ve Bahâ Saîd Bey’in Yeri”. Uluslararası Beşeri Bilimler ve Eğitim Dergisi, 5/10 (7-9 Mayıs 1992): 39-56.

Kilıç, Ersin. Alevî-Bektaşîlerin Millî Mücadeledeki Rolü ve Atatürk ile İlişkileri. Yüksek Lisans Tezi, Marmara Üniversitesi, Türkiyat Araştırmaları Enstitüsü, 2011.

Korkmaz, Esat. Ansiklopedik Alevîlik Bektaşîlik Terimleri Sözlüğü. İstanbul: Ant Yayınlar1 2. Bask1 1994.

Ocak, Ahmet Yaşar. Alevî ve Bektaşî İnançlarının İslâm Öncesi Temelleri. İstanbul: İletişim Yayınları, 2000. 2004.

Öz, Baki. İttihat-Terakki ve Bektaşîler. İstanbul: Can Yayınları,

Şapolyo, Enver Behnan. Mezhepler ve Tarikatlar Tarihi. İstanbul: Türkiye Yayınları, 1964.

Sarısır, Serdar. "Alevî-Bektaşî Zümreler Hakkında Yapılan İlk Araștırmalar". IV. Uluslararası Alevîlik ve Bekraşîlik Sempozyumu Bildiriler Kitabı, (18-20 Ekim 2018): 419-432.

Tevetoğlu, Fethi. "Millî Mücadele Kahramanlarından: Bahâ Saîd Bey". (Biga: 1882-İstanbul 16 Ekim 1939), Atatürk Araştırma Merkezi Dergisi, 6/16 (Kasım 1989): 207-221.

Tevetoğlu, Fethi. “Türkçü Dergiler III”. Türk Kültürü, 26/299 (Mart 1988): 146-155.

Tevetoğlu, Fethi. Türkiye'de Sosyalist ve Kominist Faâliyetler (1910-1960). Ankara 1967.

Türkdoğan, Orhan. Alevî-Bektaşî Kimliği/Sosyo Antropolojik Araştırma. İstanbul: Timaş Yayınları 1995. 
Ülken, Hilmi Ziya. Türkiye'de Çağdaş Düşünce Tarihi. İstanbul: Ülken Yayınları, 3. Baskı, 1992.

Yeni Sabah. "Kahraman Bahâ Saîd Öldü". Yeni Sabah Gazetesi 2/527, $19 \quad$ İlk 1939. http://ataturkkitapligi.ibb.gov.tr/kutuphane3/surely/ 03774_00527_1939M1019_197407. Pdf

\section{SUMMARY}

During the transition period from the Ottoman Empire to the Republic, Bahâ Saîd was one of our national heroes who devoted his existence to his country and nation. He completed his education and training with the rank of Staff Captain and served in the army for a short time. During the period from the Constitutional Monarchy to the proclamation of the Republic, he took active roles in political, artistic and cultural institutions such as the Turkish Hearth, the Society of National Education and Training, the Committee of Union and Progress, the Patrol Society and the National Congress. Bahâ Saîd participated in various events organized by the Turkish Hearth and provided financial support to the Turkish Hearth with the pictures he drew. Bahâ Saîd, who was appointed by the Great Leader Mustafa Kemal Atatürk during the War of Independence, toured Anatolia and organized the people. In addition, after the proclamation of the Republic, he traveled across the country and researched the religious and cultural aspects of Turkish tribes, especially the communities living in the east of the country.

Like the anonymous heroes of the War of Independence, there is not much information about the personality, life and works of Bahâ Saîd. In resources that have been published in Turkey not encountered enough information about his life story. After his death, Bahâ Saîd was recognized as one of the distinguished figures who devoted all his energy to his country, avoided fame, never avoided any dangers or sacrifices when the nation's safety and interests were at stake, and dedicated his life to his country and nation.

The first studies about Alevi-Bektashi groups in Anatolia from the 19. century were carried out by western researchers such as Browne, V. Luschan, Jacop and Hasluck. The researches in question have been evaluated as "a kind of revenge movement by Iran to undermine Islam from within." The researches in question have been evaluated as "a kind of revenge movement by Iran to undermine Islam from within." Also during this period, some western researchers called the Alevis of Anatolia as "Christian verts". They tried to bring to the agenda that the Bektashis "had a Christian effect". Against these theses put forward by Western researchers, state officials acted with 
a sense of defense and started to have researches about AleviBektashi communities.

One of the people who draws attention with his researches on Alevi-Bektashi communities is Bahâ Saîd. According to an opinion, with the recommendation of Ziya Gökalp, Bahâ Saîd was assigned by Grand Vizier Talat Pasha to closely examine Anatolian sects, AleviBektashi groups, Mustard Turkmens, Chepni and Tahtacis. According to another view, missionaries in Anatolia claimed that Alevi-Bektashi groups were "Christian verts". On the other hand, Bahâ Saîd considered it a duty to work on them. According to another view, missionaries in Anatolia claimed that Alevis-Bektashi groups were "Christian conversion". On the other hand, Bahâ Saîd considered it a duty to work on them. In fact, a magazine wrote about Bahâ Saîd because of his such works, "The irreligious children of the destroyed Turkish Hearth are now making Qizilbashism propaganda".

Either voluntarily or with the appointment of the government of Grand Vizier Talat Pasha, one of the founders of the Committee of Union and Progress, Bahâ Saîd wanted to answer that all of the views of western researchers about the Alevi-Bektashi belief in Anatolia and members of other faiths were wrong. For this reason, he conducted research on the Sociology of Alevis and Bektashis for many years, using one of the research techniques, namely participatory observation and interview methods. He spent almost half of his life studying the Ahi, Nusayris and Alevi-Bektashi communities in Anatolia.

Bahâ Saîd's researches on the subject have been published as articles in newspapers and magazines such as Türk Yurdu magazine, Muhibbân, Memleket and Meslek. His research on AlevismBektashism and Nusayri; "Alevi Communities in Turkey: Tekke Alevism-Social Alevism", "Sûfiyân chronical: Kezelbash Square I-II", "Alevi Communities in Anatolia: Tahtaci, Chepni, Mustard Turkmen Yahut Yan Batur Community", "the Hidden Temples in Anatolia: Nusayrîs and Esrar-ı Sects", "The Truth of the Word "and"Bektashîs I-III " were first published serially in the IV. and V. volumes. Bahâ Saîd's articles published in Türk Yurdu, made in the Alevi communities in Turkey are among the researches which have the best academic based methods. In addition the researches of Bahâ Saîd on these Communities also guide the recent studies. There fore, his research on his Alevi-Bektashi and Nusayriya has a separate value because it is the first in Turkey.

According to his findings, the Druze, Nusayri, Ibâdîs, Batınîs, Yazidis and especially the Bektashi and Kizilbash Communities that 
form half of Anatolia are among the free sects that can create social life. On the other hand, sects such as Nakshîism, Kadirîism and Mevlevi sects could not create a social life. However, the Alevi community, which brought together some of the Turks living in Anatolia, displayed an exemplary attitude in terms of the unity and solidarity of the society. Hac1 Bektash Veli is a person who succeeded in reconciling the primitive religions of the Turks and Manichaeism with Islam. The Bektashi rituals never lost their originality until the Yavuz period, but Bektashism underwent a revolution during the Yavuz period through Balım Sultan.

According to Bahâ Saîd, Turks settled in Anatolia both before and after Islam. After the Ottomans settled in Anatolia, a national sect, Bektashism, was born and began to decline during the time of Kanuni. Bahâ Saîd divided Bektashism into two periods as old and new. According to him, Bektashism left real works in Anatolia during these periods. In addition, the Ahi people were influenced by the Bektashis and a strong bond was formed between them. According to Bahâ Saîd, the only source of sects such as Druze, Nusayrî, Kızılbash and Bektashî is $\mathrm{Hz}$. Since it is Ali, it is more correct to call all the sects mentioned above as Alevi.

Bahâ Saîd stated that the Nusayri's affiliation with an Arab, Turkish or any other race is not certain. He especially drew attention to the fact that the Adana Nusayri have a completely different type and character. Bahâ Saîd regarded it as an important issue to make detailed and scientific studies on the elements and sources of the Nusayri people's lineage and culture, and to determine their national nature. He also drew attention to the fact that the Nusayri people are listed as Muslims in the population registers and therefore to the difficulty of obtaining precise and statistical information about their population.

In his studies, Bahâ Saîd indicated that Turkey's enemies and domestic collaborators are in an effort to disrupt the Turkish unity through sects and nations living in the east such as Armenians, Sunnis, Shiites, Kizllbashes Yazidis, Sufians, Kurds, Nasturis. According to his findings, they wanted to disrupt the Turkish unity by promising a sect to the intact Turkish ancestry living in many cities of the east.

Consequently in this study, it was aimed to determine Bahâ Saîd's researches on Alevi-Bektashi and Nusayriya communities and his thoughts on these communities. Bahâ Saîd gave general information about the origins and rites of the Alevi-Bektashi belief in his field researches. In addition, in this study, it was observed that Bahâ Saîd, who applied participatory observation and interview techniques, 
examined the belief and cultural systems of other communities in Anatolia, especially Alevis and Bektashis, and determined the presence of traces of ancient Turkish culture in them. 